\title{
TRADE AND THE GEOGRAPHIC SPREAD OF THE GREAT RECESSION *
}

\author{
Sebastian Stumpner ${ }^{\dagger}$ \\ UC Berkeley \\ Job Market Paper
}

Jan 10, 2013

For the latest version, please click here

\begin{abstract}
I use the large spatial variation in consumer demand shocks at the onset of the Great Recession to study the mechanisms behind the ensuing geographic spread of the crisis. While the initial increase in unemployment was concentrated in areas with housing busts, subsequently unemployment slowly spread across space. By 2009, it was above pre-crisis levels in almost all U.S. counties. I show that trade was an important driver of this geographic spread of the crisis. To identify the trade channel empirically, I make use of heterogeneity in the direction of trade flows across industries in the same state: Industries that sold relatively more to states with housing boom-bust cycles grew by more before the crisis and declined faster from 2007-09. These results cannot be explained by a collapse in credit supply. I then link the reduced form empirical evidence to a formal model of contagion through trade. In a quantitative exercise, the model delivers a cross-sectional effect of similar magnitude as the one found empirically and reveals that the trade channel can explain roughly half of the overall spread.
\end{abstract}

${ }^{*}$ I am especially grateful to my advisors Atif Mian, Yuriy Gorodnichenko, Andres Rodriguez-Clare, and Ted Miguel for their advice and encouragement. For useful comments and suggestions I thank Arnaud Costinot, Ben Faber, Pierre-Olivier Gourinchas, Simon Hilpert, Amir Kermani, Ross Levine, Matt Notowidigdo, David Romer, Frank Schilbach, and particularly Robin Burgess as well as seminar participants at LSE and UC Berkeley. I am also grateful for funding from the European Commission's Marie Curie Initial Training Network (AMID Fellowship)

${ }^{\dagger}$ Email: stumpner@econ.berkeley.edu 


\section{Introduction}

While the initial increase in unemployment during the Great Recession was concentrated in areas with housing busts, subsequently unemployment slowly spread across space. By 2009, it was above pre-crisis levels in almost all U.S. counties. Figure 1 maps this "geographic spread" of the crisis. How did local shocks diffuse through the economy, causing business cycle co-movement across U.S. states?

I argue that trade across U.S. states can explain a substantial fraction of the spread of the crisis across space. To the extent that producers of tradable goods across the U.S. depend on markets experiencing a housing bust and consumption collapse, they face a shock to their market size. I empirically trace the effect of these demand shocks through the trade network that connects U.S. states at the industry level. I then link the reduced form empirical evidence to a formal model of contagion through trade. In a simulation exercise, the model delivers a cross-sectional effect of similar magnitude as the one found empirically and reveals that the trade channel can explain roughly half of the overall spread.

I exploit differences in trading patterns across industries that are located in the same state to separate the trade channel from other potential contagion mechanisms. Within a state, industries differ in their shocks to market size to the extent that they depend on markets experiencing a consumption collapse. The empirical approach relies on the identification assumption that industries that sell relatively more to states experiencing a housing bust are not relatively more affected by other shocks. Thus, other potentially confounding shocks (such as credit supply shocks or expectation shocks) are controlled for to the extent that they do not affect industries differentially in a way that is correlated with the direction of trade flows.

My empirical analysis finds a sizable role for trade in the transmission of the crisis: First, I find that a one standard deviation in the variable measuring exposure to demand shocks causes a 3 percentage point difference in 2007-09 employment growth, which corresponds to $20 \%$ of the total dispersion in employment growth among tradable producers. This result is robust to focusing only on variation in trade flows that arises from different transportation costs across industries. Moreover, it is specific to trade flows to, but not trade flows from highly levered states. Second, to learn about the role of trade in the transmission of business

cycles more generally, I study the dynamic evolution of the industries over a longer (10 year) horizon. I find that industries selling particularly to high-leverage states were booming before the crisis, thus benefitting from the housing and consumption boom in these states. This pattern reverses with the beginning of the recession in 2007 and reaches a low in 2009 (when the national unemployment rate peaked). With the recovery starting in 2009, the 
differential effect across industries again slowly converges back to zero. I thus find evidence that strongly supports the view that trade in goods is important for linking fluctuations across states.

An additional test based on industry heterogeneity in product differentiation further supports the main empirical results. A standard Armington model with heterogeneity in product differentiation across industries predicts that the reduction in employment following a shock to market size is stronger for industries producing more differentiated goods. The reason is that a higher degree of product differentiation results in a lower trade elasticity, i.e. a lower sensitivity of trade flows to costs: Industries producing more homogeneous output can more easily offset a shock to a particular market by increasing their market share at other destinations. I find precisely this pattern of differential adjustment in the data, which further supports the main empirical results on the trade channel.

The results on the trade channel cannot be explained by a credit supply shock. An adverse shock to credit supply may be viewed as the main competing mechanism for the trade channel in spreading the crisis: Due to the collapse in their asset values and troubles in the interbank lending market, commercial banks may have cut their credit supply to businesses. I construct a variable measuring the credit supply shock at the county level, making use of heterogeneity in pre-crisis bank health and in bank market shares across counties. I find that the effect of the trade channel remains unchanged when the credit supply shock is controlled for.

Finally, a model of crisis diffusion through trade allows me to assess general equilibrium effects and to gauge the aggregate contribution of trade to the spread of the crisis. While the reduced-form estimates can econometrically identify the role of the trade channel, they only inform me about the relative magnitude of the shock across industries. To assess the overall contribution of trade to the spread of the crisis, I build a model that captures the geographic diffusion of the crisis through trade. The model is built so that it maps directly into the states and industries observed in the empirical part. I compute the model's response to the expenditure shocks at the state level that are observed empirically, and then re-run the same regressions on the model-implied values. The model yields coefficients that are of similar magnitude to the ones found empirically. I then use the model to ask questions that the empirical part cannot answer: I identify general equilibrium channels that determine the model's response, and compute the share of the crisis spread that the trade channel can account for. I define the total spread of the crisis in the model as the deviation in growth at the state level between the data and the growth that would have prevailed if each state was a closed economy. The spread of the crisis refers to the redistribution of the crisis across states (as opposed to amplification). Using a within-model comparison, I compute how much closer the trade model gets to the data, compared to the closed economy. This share of trade 
is roughly half.

This project relates to several strands of literature. First, it relates to the literature that highlights the role of demand shocks as the main trigger of the recession. On the theory side, Midrigan and Philippon (2011) and Eggertsson and Krugman (2012) provide models of the recession driven by a collapse in aggregate demand. On the empirical side, Mian et al. (2012), using micro consumption data, document the fall in consumer demand as a result of the housing bust. Mian and Sufi (2011b) show that this collapse in consumption was the main driver of unemployment in cities that experienced housing boom and bust cycles. I use the demand shocks identified by these authors and trace their effect through the within-U.S. trade network.

Second, this paper is closely connected to the literature on trade, volatility, and business cycle comovement. Frankel and Rose (1998) were the first to highlight that countries that trade more with each other tend to have more correlated economic outcomes. Following this work, several papers have investigated the relationship between trade openness and volatility and trade openness and output comovement. Typically, this literature has focused on the statistical association between trade openness and the variance of output growth or the correlation of output growth across countries. ${ }^{1}$ My paper complements this literature by studying the diffusion of a specific shock across space through the trade channel.

Finally, this work is related to the literature on the contagion of crises, such as van Rijckeghem and Weder (2001), Glick and Rose (1999), and Kaminsky and Reinhart (2000). This line of literature has mostly focused on estimating the channels of contagion across countries using aggregate data on cross-country financial and trade linkages. In contrast, I focus entirely on within-country contagion, and use industry heterogeneity in the direction of trade flows to identify the trade channel.

\section{Empirical Strategy}

My identification approach exploits within-state across-industry heterogeneity in exposure to demand shocks. To do so, I first define a measure of exposure to demand shocks through trade as motivated by a general expenditure system. I use differences in trading patterns across industries in the same state to identify which industries should be relatively more affected by demand shocks. This industry heterogeneity allows me to separate the trade channel from potentially confounding mechanisms.

\footnotetext{
${ }^{1}$ Recent examples are di Giovanni and Levchenko (2009) who study the relationship between trade openness and volatility in a panel of countries and industries, and di Giovanni and Levchenko (2010) who highlight the role of vertical linkages between industries for cross-country economic comovement.
} 
Consider the problem of measuring the spread of consumer demand shocks through a trade network. In principle, these demand shocks will entail direct effects on producers through lower demand, and indirect effects through general equilibrium changes in wages and prices. ${ }^{2}$

For the empirical part, I derive a measure of exposure to demand shocks by focusing only on direct effects, similar to Autor et al. (2012). This has the advantage that I can avoid making specific modeling assumptions that the derivation of general equilibrium effects would require. It does not assume, however, that general equilibrium effects are absent. The strategy is to derive a measure of exposure to demand shocks, and then to analyze the adjustment at the state-industry level. I defer a model-based discussion of general equilibrium effects and their role for the empirical estimates to a later section of the paper.

I consider the spending side of a simple Armington trade model with $N$ states and $S$ industries. Each state n produces only one distinct variety in each industry, and consumes an aggregate of goods from all industries:

$$
C_{n}=\prod_{k}\left(C_{n}^{k}\right)^{\alpha^{k}}
$$

where $C_{n}$ is aggregate consumption in state $n$ and $C_{n}^{k}$ is consumption by state $n$ of varieties in industry $k$. This leads to constant expenditure shares across all industries, $X_{n}^{k}=\alpha^{k} X_{n}$, and unit income elasticities for all goods. The real consumption by state $n$ of the good produced by state $i$ in industry $k$ is denoted by $c_{n i}^{k}$ with price $p_{n i}^{k}$. Total consumption of the good in industry $k$ by state $n$ is a CES aggregate of the varieties coming from all states: ${ }^{3}$

$$
C_{n}^{k}=\left(\sum_{i}\left(c_{n i}^{k}\right)^{\frac{\sigma-1}{\sigma}}\right)^{\frac{\sigma}{\sigma-1}}
$$

The price index for industry $k$ in state $n$ is denoted $P_{n}^{k}$. Prices differ across states due to trade costs. Expenditure by state $n$ on the variety produced by state $i$ in industry $k$ is then a function of total expenditure in state $n$.

$$
X_{n i}^{k}=\left(\frac{P_{n}^{k}}{p_{n i}^{k}}\right)^{\sigma-1} \alpha^{k} X_{n}
$$

Total sales by state $i$, industry $k$, can then be written as a function of expenditure at all

\footnotetext{
${ }^{2}$ In general equilibrium, expenditure shocks may affect wages (and therefore prices) through shifts of both the labor demand and the labor supply curve.

${ }^{3}$ This expenditure system could be generalized to include state-industry specific expenditure shares $\alpha_{n}^{k}$, a state-industry specific elasticity of substitution $\sigma_{n}^{k}$ and preference parameters $\omega_{n i}^{k}$ to accommodate, for instance, home bias in goods. This generalization would not affect equation 1.
} 
destinations:

$$
Y_{i}^{k}=\sum_{n} X_{n i}^{k}=\sum_{n}\left(\frac{P_{n}^{k}}{p_{n i}^{k}}\right)^{\sigma-1} \alpha^{k} X_{n}
$$

The idea is to capture the shocks to household balance sheets in states with high leverage and strong house price declines as shocks to consumer expenditure. In terms of the model, these are shocks to $X_{n}$. Considering only the direct effect of these shocks, changes in production at the origin state $i$ in industry $k$ can be written as follows.

$$
\mathrm{d} \log \left(Y_{i}^{k}\right)=\sum_{n} \frac{X_{n i}^{k}}{Y_{i}^{k}} \mathrm{~d} \log \left(X_{n}\right)
$$

In general equilibrium, growth of industry sales and consumer expenditure are jointly determined. In a regression framework, this leads to a simultaneity problem. In order to estimate the role of trade in transmitting the crisis, I need exogenous variation in expenditure growth. Work by Mian et al. (2012) has shown that pre-crisis household leverage had a strong effect on expenditure growth during the recession. In 2006, there were large differences in household leverage across U.S. states. A large part of these differences were due to differences in leverage growth from 2002 to 2006. Strong house price growth in some U.S. states during that time led to a buildup of leverage, driven to a large extent by home equity withdrawals (Mian and Sufi, 2011a). At the peak of the housing bubble in 2006, states with rapid house price growth during 2002-06 also tended to have the most highly indebted households. With the reversal of house prices starting in 2006, highly levered households experienced significantly lower expenditure growth, compared to households with low leverage (Mian et al., 2012). I therefore use pre-crisis household leverage as an initial shock to expenditure growth, which is not subject to simultaneity concerns.

I define the trade demand shock at the state $i$, industry $k$ level as follows:

$$
\operatorname{TDS}_{i}^{k}=\sum_{n=1}^{N} \frac{X_{n i}^{k}}{Y_{i}^{k}} \operatorname{Lev}_{n}
$$

TDS is the weighted sum of destination-state pre-crisis household leverage, where the weights are given by outgoing trade shares. ${ }^{4}$

I estimate the reduced form effect of the trade demand shock variable on industry out-

\footnotetext{
${ }^{4}$ I aggregate county-level leverage ratios to the state-level using the number of households in a county as weights. The fraction of total shipments in industry $k$ from state $i$ to destination $n, \frac{X_{n i}^{k}}{Y_{i}^{k}}$, is observed from shipments data detailed in the next section.
} 
comes. ${ }^{5}$ In particular, I consider the following specification:

$$
\mathrm{d} \log \left(Y_{i}^{k}\right)=\beta_{0}+\beta_{1} \operatorname{TDS}_{i}^{k}+\gamma_{i}+\alpha^{k}+\epsilon_{i}^{k}
$$

where $Y$ stands for employment, earnings, or the average wage. ${ }^{6}$ By adding a state fixed effect $\gamma_{i}$, the estimation makes use of differences in trading patterns across industries within a state. The industry fixed effect $\alpha^{k}$ controls for shocks that hit all producers in a specific industry.

The main endogeneity concern for the estimation of equation 2 is one of omitted variable bias: In addition to a demand shock that is transmitted through trade, a particular region (i.e. a county or a state) may be subject to other shocks that also affect economic outcomes. If these shocks are unobserved and correlated with the trade demand shock, the estimated coefficient of interest will be inconsistent. For instance, employment may decline due to a contraction in local credit supply, or due to expectation shocks. If regions that trade more with high-leverage states are also subject to larger credit supply shocks or stronger adverse expectation shocks, then an approach that only links regional employment growth to a measure of exposure to demand shocks through trade is problematic.

The idea of the identification strategy is to make use of cross-industry heterogeneity in the exposure to demand shocks through trade: Within a state, industries that trade relatively more with high-leverage states should experience a stronger economic decline. The identification assumption is that these industries are not relatively more affected by other shocks. That is, within a state, any unobserved shocks that affect state-industry level outcomes are not higher (or lower) for industries that sell relatively more to high-leverage states pre-crisis. ${ }^{7}$

\footnotetext{
${ }^{5} \mathrm{I}$ only present results for the reduced form, because no good data for expenditure growth at the state level are available.

${ }^{6}$ Since I do not observe industry sales, I use changes in log employment and wage payments as dependent variables. In the case of a Cobb-Douglas production function and constant markups, the percentage change in wage payments equals the percentage change in sales.

${ }^{7}$ In mathematical terms, consider the framework

$$
y_{s i}=\beta_{0}+\beta_{1} x_{s i}+\alpha_{s}+\gamma_{i}+\epsilon_{s i}
$$

where $\alpha_{s}$ and $\gamma_{i}$ are fixed effects and $\epsilon_{s i}=z_{s i}+\nu_{s i} . z_{s i}$ is an omitted variable and $\nu_{s i}$ is an i.i.d. error term with mean zero. The transformed model is:

$$
\tilde{y}_{s i}=\beta_{0}+\beta_{1} \tilde{x}_{s i}+\tilde{z}_{s i}+\tilde{\nu}_{s i}
$$

Taking the conditional expectation:

$$
E\left[\tilde{y}_{s i} \mid \tilde{x}_{s i}\right]=\beta_{0}+\beta_{1} \tilde{x}_{s i}+E\left[\tilde{z}_{s i} \mid \tilde{x}_{s i}\right]
$$

since $E\left[\tilde{\nu}_{s i} \mid \tilde{x}_{s i}\right]=0$. The identification assumption is that $E\left[\tilde{z}_{s i} \mid \tilde{x}_{s i}\right]=0$. In words: Within a state, industries that ship relatively more to high-leverage states are not more affected by another shock than other industries in the same state.
} 
The validity of the identification assumption depends on what drives the variation in the measure of trade demand shocks. To put it differently, why do trading patterns differ across industries in the same state? If the source of this heterogeneity is plausibly exogenous to other shocks, the identification assumption is valid.

Figures 2 and 3 show that distance plays an important role in intra-U.S. trade and that the effect of distance varies systematically across industries. Figure 2 plots aggregate (i.e. state-to-state) trade flows against distance, and shows that states that are further apart trade significantly less on average. However, the aggregate effect of distance hides substantial variation at the industry level: Figure 3 plots the average distance (in miles) traveled by shipments in an industry against the log of the value-to-weight ratio, a common (inverse) measure of transportation costs. ${ }^{8}$ Industries with higher transportation costs (i.e. lower value-to-weight ratio) trade over much shorter distances. The effect of transportation costs on trade thus implies that in high-leverage states, industries with lower transportation costs should experience a lower demand shock (compared to industries with high transport costs), because they ship more out-of-state. Similarly, in low leverage states, they should be relatively more affected than high-transportation cost industries. For other shocks (like credit supply or expectation shocks) to play a confounding role, they would have to imply similar cross-sectional effects. Since transportation costs are arguably a technological characteristic of an industry, there is no immediate reason to believe that other shocks would cause a similar cross-sectional pattern.

One may worry that industries receive financing from their destination states. If industries that trade more with high-leverage states also receive more financing from these states, and credit supply shocks were larger among banks in high-leverage states, the estimated coefficient of interest would be inconsistent. However, in practice this is unlikely to be a major concern. While the distance between lenders and borrowers has generally increased over the last decades, Brevoort et al. (2010) find that, in 2003, the median distance between a firm and its bank was still only 11 miles.

One last check on the identification strategy is to make sure that there is significant variation in the trade demand shock variable. This requires not only variation in trading patterns across industries in the same state, but also variation in demand shocks at the state-level. Mian and Sufi (2011b) use variation in household leverage at the county level to identify the effect of local demand shocks on local employment. This variation in county leverage is to a large degree driven by variation across states: A regression of county leverage on a set of fixed effects delivers an $R^{2}$ of $48 \%$ in an unweighted regression ( $72 \%$ if weighted by

\footnotetext{
${ }^{8} \mathrm{I}$ construct it by dividing the total value of all shipments in an industry by the overall tonnage of these shipments.
} 
the number of households). Across states, household leverage ranges from 1.15 in Mississippi to 3.08 in California, thus providing substantial variation of demand shocks across states.

Figure 4 visualizes this variation by plotting the 5 th, $25 \mathrm{th}, 75 \mathrm{th}$, and 95 th percentile of the trade demand shock variable within each state. The horizontal axis sorts states by 2006 $\mathrm{HH}$ leverage, and the boxes show the range of the trade demand shock across industries within that state. On average, industries in states with higher leverage face higher demand shocks. This is a natural consequence of the home bias in shipments: A sizable part of shipments stays within the same state. However, this variation across states will not be used in the main set of regressions, since it is controlled for by a state fixed effect. Instead, I use the variation across industries within a state, which is represented in the graph by the vertical spread of the boxes.

\section{Data and Summary Statistics}

This section describes the data used in this study and provides basic summary statistics. I put a particular emphasis on the trade flow data. These data allow me to discern heterogeneity in exposure to demand shocks across industries based on the direction of trade flows. I then give a brief overview of other datasets and discuss summary statistics.

\subsection{Trade Flow Data}

To measure trade flows across states, I turn to the Commodity Flow Survey (CFS) that is administered by the U.S. Census Bureau. Since the CFS is only conducted every five years together with the Economic Census, the latest trade flow data available are for 2007 . The CFS captures data on shipments originating from selected types of business establishments located in the 50 states and the District of Columbia. The survey reports the value of shipments, where the value is defined as the net selling value, f.o.b plant, exclusive of freight charges and excise taxes. Based on the shipment records of enterprises, the Census Bureau estimates trade flows between regions (states or other CFS defined areas) at the aggregate level and at the level of industries/commodities. To make the trade flows directly comparable to the employment records, I turn to the CFS origin-destination tables at the NAICS industry level.

There are several caveats of the data that require more detailed discussion. First, for some combinations of origin, destination, and industry, the Census Bureau only observes very few shipment records. In case the precision of the estimates is too low, the CFS withholds information and these entries appear as missing values in the data. I use the state-to-state industry-level table in which these missing entries only account for $15 \%$ of the value of to- 
tal measured trade flows. ${ }^{9}$ For the empirical implementation, I set these missing entries to zero. ${ }^{10}$ For D.C., Alaska, and Hawaii, the table features many missing trade flows, which is why I disregard these states altogether. To further improve on data quality, I discard observations that have less than $\$ 25$ million worth of total shipments (and which therefore have many missing values). Finally, to arrive at a more homogeneous sample of industries, I focus only on 39 of the 45 NAICS industries covered in the CFS, namely on all manufacturing (21) and all wholesale trade (18) industries. ${ }^{11}$

Next, the CFS data also capture shipments that are related to international trade. In the case of an international destination, the CFS records the U.S. port of exit as domestic destination. ${ }^{12}$ Shipments that originated as imports are included to the extent that they are shipped within the U.S. to their final destination from one of the surveyed firms. Unfortunately, the state-to-state trade data from the CFS do not allow me to distinguish between purely domestic shipments, and shipments to or from other countries. While the U.S. Census collects information on exports in the CFS, these information are not made available in the state-to-state industry table. ${ }^{13}$ However, information on exports are made available at a higher level of aggregation. This data reveals that, compared to the total value of shipments, exports are relatively small in value. The total value of all shipments of my sample of industries in the 2007 CFS is $\$ 10.2$ trillion. In comparison, the total value of exports of these industries in the 2007 CFS is $\$ 822$ billion, only $8.1 \%$ of all shipments. ${ }^{14}$

While the CFS collects data on exports, it does not provide information on whether a shipment originated as an import. However, it is important to note that I only focus on shipments that originate from domestic manufacturing establishments or wholesale traders. According to Bernard et al. (2009), the presence of wholesale and retail trade firms is more important in U.S. imports than it is in exports. ${ }^{15}$ Wholesale traders are likely to reduce their employment when demand at their destinations dries up, but it should not matter whether the shipped products were originally imported or not. For wholesale traders, it is therefore desirable to include shipments that were imported. In contrast, manufacturers are more likely to use im-

\footnotetext{
${ }^{9}$ Total outgoing flows for a state-industry are reported separately. This allows calculating the fraction of total flows that missing values account for.

${ }^{10}$ In a robustness exercise, I impute these missing values based on predicted values from a gravity model, and then re-do the main empirical analysis. I find that the results remain unchanged.

${ }^{11}$ I therefore exclude Mining (NAICS 212), Electronic Shopping and Mail-Order Houses (4541), Warehousing and Storage (4931), Newspaper, Periodical, Book, and Directory Publishers (5111), Fuel Dealers (45431), and Corporate, Subsidiary, and Regional Managing Offices (551114).

${ }^{12}$ The CFS does collect data on exports, but these information are not publicly available in the state-to-state NAICS files.

${ }^{13}$ In contrast, information on a potential foreign origin of a shipment are not collected in the CFS.

${ }^{14}$ Focusing only on manufacturing industries, this ratio is $10.3 \%$.

${ }^{15}$ According to Bernard et al. (2009), wholesale traders account for $63 \%$ of the number of importing firms and $27 \%$ of the total value of imports (vs. $10 \%$ of the value of exports).
} 
ported products as inputs for production (instead of resale). Imported products would then pose a problem, if they result in a domestic shipment that originates from a manufacturing firm. For instance, a manufacturing plant could ship the imported product to a downstream plant of the same firm. However, as Atalay et al. (2012) note, this kind of shipments is very rare in the U.S.. It then seems more likely that manufacturers use imported products directly in the plants in which the shipments arrive. In this case, the shipments would not be part of my data. It is therefore highly unlikely that imports have a significant influence on the empirical results.

\subsection{Other Datasets}

Annual data for employment and wage payments of industries at the state and county level come from the U.S. Census County Business Patterns (CBP). For monthly data on employment of industries I turn to the publicly available files from the BLS Quarterly Census of Employment and Wages (QCEW). The trade data from the CFS come in a more aggregated format in terms on industries, and therefore determine the level of my analysis. Finally, I will use data on county-level household leverage from the Federal Reserve Bank of New York Consumer Credit Panel.

\subsection{Summary Statistics}

Table 1 shows summary statistics of employment growth and the trade demand shock variable at the state-industry level for the sample of manufacturing and wholesale trade industries. On average, employment fell by $8 \%$ between 2007 and 2009, with substantial heterogeneity across industries. Moreover, variation in employment growth accounts for most of the variation in changes of the total wage bill. Table 2 shows summary statistics of the level of employment in 2007, and the level of the total wage bill (in million $\$$ ) and the average wage.

Figure 5 gives a slightly different view of the expenditure imbalances across states at the beginning of the crisis. It shows the state-level trade deficit (calculated from the CFS) against HH leverage: The higher expenditure of high-leverage-states are mirrored in their sizable trade deficits against other states.

Although the crisis started with demand shocks in high-leverage states, by 2009 unemployment was on the rise almost everywhere across the U.S. If trade is an important factor for the geographic spread of the crisis, we would expect that tradable industries account for a sizeable share of the jobs lost in low-leverage states. Figure 6 plots the jobs lost in manufacturing (2007-09) as a share of the total jobs lost in that state against the pre-crisis 
household leverage. It shows that manufacturing alone accounts for a large fraction of the jobs lost in low-leverage states, in some states even over $50 \%$.

\section{Trade Channel Results}

This section shows empirically that the trade channel was important for spreading the crisis across space. First I show that industries that were relatively more dependent on markets with housing boom-bust cycles declined by more during the crisis period. Second, this comovement is not restricted to the crisis period. The same industries tended to grow relatively faster during the housing boom period preceding the recession. This result establishes empirically that, more generally, trade links business cycles across space.

The main results hold in several robustness checks. Most importantly, these patterns are specific to trade flows to, but not trade flows from states with housing bubbles. They are also robust to restricting the variation in trade flows to the part that can be explained by distance and different transportation costs across industries.

\subsection{The Trade Channel During the Crisis}

I find that industries selling relatively more to states with high household leverage declined by more during the crisis. This effect is more pronounced for employment than for the average wage. It holds for pooling manufacturing and wholesale trade industries, and also when I restrict attention to manufacturing industries only.

I estimate equation 2 using growth in employment, earnings, and the average wage (i.e. earnings divided by employment) as left hand side variables. ${ }^{16}$ For each dependent variable, I run an unweighted and a weighted least squares specification, using 2007 employment of the state-industry cell as weight. Standard errors are twoway clustered at the state and industry level. If the trade channel is relevant for transmitting shocks, we would expect $\beta_{1}<0$.

Table 3 shows a negative and large effect of the trade demand shock on state-industry level employment and earnings. The point estimate reveals that a one standard deviation increase in the trade demand shock causes a reduction in employment growth by approximately 3 percentage points. Given a standard deviation of employment growth of 16 percentage points, this corresponds to almost $20 \%$ of a standard deviation. The fall in employment accounts for most of the earnings adjustment (70\%-80\%), while the remainder is accounted for by the average wage.

\footnotetext{
${ }^{16}$ By definition of the average wage, the coefficients in the employment and wage regressions have to sum up to the coefficient obtained in the earnings regression.
} 
The coefficient is considerably larger than the estimates in Mian and Sufi (2011b) who look at the relationship between household leverage and local nontradable employment growth. These authors report a coefficient of approximately -0.02 , which is substantially smaller than my estimate of -0.09 . The fact that my estimates are larger in magnitude likely reflects compositional changes in demand, i.e. a shift in spending away from tradable goods. In the context of international trade, these compositional changes have already been noted by Eaton et al. (2011) and Levchenko et al. (2010) and are found to explain a large part of the fall in global trade relative to GDP. My estimates are thus consistent with the findings of these authors.

Results from focusing only on manufacturing industries are similar to the previous set of results (Table 4).

\subsection{The Trade Channel over the recent Business Cycle}

Studying the relationship between trading patterns and industry growth over a longer horizon reveals that trade caused comovement of the entire recent business cycle: Prior to the crisis, consumption grew rapidly in states with a housing boom. This led to faster growth of industries selling predominantly to these states.

To track the recent business cycle, I estimate equation 2 for a sequence of rolling windows of two-year employment growth. I use monthly employment data available from the BLS for a better alignment of time with the key events during the Great Recession. ${ }^{17}$ I start with the window of Jan 2002 - Jan 2004, and end with Dec 2009 - Dec 2011 to include the evolution of the coefficient during the years of the credit boom, the crisis, and the recovery.

If trade links business cycles across states, then the coefficient should be positive before the crisis. As Mian and Sufi (2011a) document, high pre-crisis leverage was largely a result of high growth in leverage during the years 2002-2006. In places with high growth of house prices, homeowners extracted new debt from the rising value of their homes to finance ongoing consumption. We would then expect that industries that sold primarily to states with high pre-crisis leverage were booming in the pre-crisis period.

Figure 7 shows that exactly this pattern holds in the data. It is only in mid-2007 that the coefficient turns negative (roughly one year after the Case-Shiller house price index peaks). Starting in 2009 it slowly reverses and approaches zero during the period of the recovery. By 2011, industries selling primarily to high-leverage states show no difference in growth from the control industries.

Figure 7 is also evidence that the results obtained in the previous subsection are not caused

\footnotetext{
${ }^{17}$ Since data for wholesale industries are not available for the early years, this exercise is conducted using only data for manufacturing industries.
} 
by different pre-existing trends. If that was the case, industries selling to high-leverage states would have been growing more slowly even before the crisis. The fact that the coefficient is positive confirms instead the role of trade in transmitting shocks across space.

\subsection{Robustness}

This subsection presents a set of robustness checks, each addressing a specific concern one may have about the previous estimations. I start by restricting the source of variation in trade flows. Without a clear idea of what is driving the variation in trade flows across industries in a state, it is hard to discuss the validity of the identification strategy. In the first exercise, I therefore limit the variation in trade flows to the part that can be explained by different transportation costs across industries.

\section{Restricting the Variation in Trade Flows}

One concern with the previous analysis may be that the source of variation in trade flows is left unclear. In the following empirical exercise, I instead restrict attention to variation in trade flows that arises from different transportation costs across industries. I compute predicted trade flows from a structural gravity framework, using state-to-state distance and the industry-specific value-to-weight ratio to measure transportation costs. Using these predicted trade flows, I re-compute the trade demand shock. In a final step, I use the newly constructed variable as an instrument for the trade demand shock. I find the main results from the previous section unchanged.

The value-to-weight measure is calculated from the commodity flow survey data as the aggregate value of all shipments of an industry divided by the aggregate tonnage of shipments. Differences in the value to weight ratio are enormous and range from $\$ 110$ per ton shippped (Nonmetallic Mineral Products) to $\$ 71,000$ per ton (Computer and Electronic Products). Distance is defined as the great circle distance between the population-weighted centers of two states.

To consistently estimate the effect of trade costs on trade flows, I follow the literature on estimation of gravity equations (Head and Mayer, 2013). A wide variety of trade models yields an expression for trade flows that can be written in log form as follows:

$$
\log \left(X_{n i}^{k}\right)=\log (G)+\log \left(S_{i}^{k}\right)+\log \left(M_{n}^{k}\right)+\log \left(\phi_{n i}^{k}\right)
$$

In this expression, $S_{i}^{k}$ denotes all factors that promote exports of industry $k$ in state $i$ to all destinations, and $M_{n}^{k}$ all factors that promote imports. Pinning down the exact expressions for $S_{i}^{k}$ and $M_{n}^{k}$ would require more structure at this point. Finally, the variable $\phi_{n i}^{k}$ captures 
trade costs, and $G$ is a constant. To consistently estimate the effect of trade costs on trade flows, I employ a fixed effects model which is standard in the gravity literature. To that end, I use exporter-industry and importer-industry fixed effects to control for $S_{i}^{k}$ and $M_{n}^{k}$, respectively.

Modeling trade costs using an interaction between distance and the value-to-weight ratio parsimoniously captures the heterogeneous effect of distance on trade flows across industries. More specifically, I model trade costs as

$$
\log \left(\phi_{n i}^{k}\right)=\beta \log \left(\text { Distance }_{n i}\right)+\delta \log \left(\text { Distance }_{n i}\right) \cdot \log \left(\text { Value-to-weight }^{k}\right)
$$

To see that this model does a good job at fitting the heterogeneity in trade costs across industries, first consider a nonparametric approach:

$$
\log \left(X_{n i}^{k}\right)=\alpha_{i}^{k}+\gamma_{n}^{k}+\sum_{l=1}^{S} \beta^{l} \cdot \log \left(\text { Distance }_{n i}\right) \cdot d^{l}+\epsilon_{n i}^{k}
$$

That is, I first estimate the effect of distance on trade flows industry-by-industry, where $d_{l}$ is a dummy for industry $l$. The effect of distance is thus allowed to vary by industry. Figure 8 plots the $\beta_{l}$ coefficients against the log of the value-to-weight ratio of the respective industry.

As expected, the graph shows a positive relationship between the two: Distance is less of a barrier for trade flows in industries with a higher value-to-weight ratio. Moreover, the graph shows that a linear fit does a good job at describing the heterogeneity of the effect of distance across industries. This suggests the following estimation equation:

$$
\log \left(X_{n i}^{k}\right)=\alpha_{i}^{k}+\gamma_{n}^{k}+\beta \log \left(\text { Distance }_{n i}\right)+\delta \log \left(\text { Distance }_{n i}\right) \cdot \log \left(\text { Value-to-weight }^{k}\right)+\epsilon_{n i}^{k}
$$

Results are in table 5. As expected, they show a strong negative effect of distance on trade flows, which is muted in industries with high value-to-weight ratios.

I then re-construct the trade demand shock variable based on predicted trade flows $\hat{X}_{n i}^{k}$ :

$$
T D S I V \equiv \sum_{n} \frac{\hat{X}_{n i}^{k}}{\sum_{n} \hat{X}_{n i}^{k}} L e v_{n}
$$

Table 6 shows the first and second stage results. The first stage yields a F-statistic of 45, showing the relevance of the instrument. The second stage yields coefficient estimates that are very similar to the simple least squares estimates. 


\section{Out-of-state trade flows}

Next, I test specifically for the diffusion of the crisis across state borders. To do so, I define a new variable, which only captures variation in demand shocks through out-of-state trade flows. That is, I define

$$
\text { External } \operatorname{TDS}_{i}^{k}=\sum_{n \neq i} \frac{X_{n i}^{k}}{\sum_{n \neq i} X_{n i}^{k}} \operatorname{Lev06} 6_{n}
$$

Just as the variable TDS, this variable is measured in leverage points, since the weights sum up to one. I then re-do the main estimations using this variable as regressor. Results can be seen in table 7 . The effect is negative and significant for both employment growth and labor income growth. The magnitude of the effect is smaller compared to the effect of the main estimations, using the TDS variable. This is expected, because out-of-state trade flows only account for $52 \%$ of all trade flows (average across state-industries), and the effect of out-of-state demand shocks should thus be lower than the effect of all demand shocks.

\section{Reverse Trade Flows}

If demand shocks in housing boom and bust states triggered the crisis, then it should be exports to, but not imports from these states that transmit the crisis across space. I use this idea to run a placebo test, constructing the right-hand-side variable with incoming, instead of outgoing trade flows. If most of bilateral trade is intra-industry (instead of inter-industry), then exports and imports would be highly correlated. As a consequence, the variables using either incoming or outgoing trade flows as weights would yield high correlation. In contrast, the two variables may differ if a substantial part of trade is inter-industry.

I thus construct a variable called Reverse-TDS by using incoming instead of outgoing trade flows:

$$
\text { Reverse } \operatorname{TDS}_{i}^{k}=\sum_{n} \frac{X_{i n}^{k}}{\sum_{n} X_{i n}^{k}} \operatorname{Lev} 06_{n}
$$

That is, Reverse-TDS captures the weighted leverage of shipment origin states, where the weights are given by import shares. After controlling for industry and state fixed effects, this variable is only moderately correlated with the original trade demand shock measure. The correlation coefficient is 0.35 , thus leaving room to disentangle the effect of these two variables empirically. I use the original variable and the newly constructed one in a joint regression to separate the effects. Table 8 presents the results of this exercise. It shows that the coefficient on the original variable is unchanged, while the coefficient on the variable using reverse trade flows is indistinguishable from zero. This suggests that trade-transmitted demand shocks 
spread the crisis across space.

\section{Internal Trade Share}

One concern with the previous set of estimations may be that the variable of interest only captures different exposure of industries to within-state demand shocks. In that case, there would be no diffusion of the crisis across state borders, and the crisis would remain local. To test whether this is a concern, I augment specification 2 by the internal trade share of a state-industry, and let the effect of the internal trade share on the industry outcome vary by state. Results are in table 9. The coefficients on the trade shock remain unchanged. Only standard errors increase, because the rich set of interactions absorbs some of the variation in the data. Overall, the results suggest that exposure to internal shocks does not drive the effect measured in the previous section.

\section{Industry-specific demand shocks}

Next, one may worry that the main specification of an industry's exposure to demand shocks is too simplistic. In particular, industries may differ in the intensity of shocks to their particular demand, given a fall in aggregate expenditure at a destination. For instance, this can be caused by different income elasticities of consumers for goods produced by different industries. ${ }^{18}$ In this section, I test for robustness of the main empirical results to using alternative measures of the trade demand shock adjusted for heterogeneous exposure.

In the absence of measures of expenditure elasticities at the industry level, I rely on aggregate data on the fall in economic activity for industries. More precisely, I calculate the relative gross growth rate of earnings at the national industry level as $\mu_{k}=\frac{1+g^{k}}{1+g}$. The idea is that industries that declined by more nationally (i.e. for which $\mu_{k}$ is low) were more exposed to demand shocks. For a given collapse in total expenditure at a destination (as proxied by leverage), the demand shock should thus be worse for industries that declined by more during the recession. I therefore divide leverage by $\mu_{k}$ to arrive at an industry-level demand shock. The adjusted trade demand shock variable can be written as

$$
T D S I_{i}^{k} \equiv \frac{T D S_{i}^{k}}{\mu_{k}}
$$

Results are presented in table 10 and are robust to this adjustment.

\footnotetext{
${ }^{18}$ Mian et al. (2012) present some evidence for this heterogeneity in consumer spending.
} 


\section{Splitting up by Destination}

One concern with the previous estimations may be that the effect is driven by only a few destination states, that happen to be high-leverage states. In this section I investigate whether the significant effect on the trade demand shock indeed resembles a systematic effect of destination-state leverage, or if it merely reflects shocks to a few destinations that happen to be correlated with leverage. To do so, I split up the main regression by export destination. That is, I generalize equation 2 to the following setup:

$$
d \log \left(L_{i}^{k}\right)=\sum_{n=1}^{50} \beta_{1 n} E D_{n i}^{k}+\gamma_{i}+\alpha_{k}+\epsilon_{i}^{k}
$$

where $E D_{\text {sid }}$ is defined as export dependence of industry $i$ in state $s$ on destination $d$. It

is simply the industry's share of shipments that go to destination $d: E D_{n i}^{k}=\frac{X_{n i}^{k}}{Y_{i}^{k}}$. Because these shares sum to one, no constant is included in the regression. Notice that equation 3 collapses to equation 2 in the special case of $\beta_{1 n}=\operatorname{Lev06} 6_{n}$. I estimate the equation and extract the coefficient estimates $\hat{\beta}_{1 n}$. Figure 9 plots the estimated coefficients against the state-level household leverage at the destination state. The graph shows a negative relationship, and demonstrates that the coefficient is systematically related to state-level household leverage. The slope is roughly in line with the results of the TDS regressions in table 3. The estimated coefficients can be interpreted as follows: Comparing two states on the regression line, e.g. Florida $\left(\beta_{F L}=-0.11\right)$ and $\operatorname{Texas}\left(\beta_{T X}=-0.02\right)$, an increase in the export share by $10 \mathrm{ppt}$ to Florida vs. Texas would be associated with a lower employment growth of 0.9 percentage points.

\subsection{Differentiated vs. Homogeneous Goods}

Next, I consider differential effects across manufacturing industries, depending on the type of goods they produce. The main idea of contagion through trade is inherently related to the idea that producers cannot substitute their customers easily. If an industry's output was sold on a single spot market, then heterogeneity in demand shocks across regions would not introduce heterogeneity in producer growth: Producers can substitute costlessly between buyers, and demand shocks are averaged out between producers. I use this intuition to test for the idea that geographic contagion through trade should mainly occur in industries that sell differentiated products. I use Rauch's classification (Rauch (1999)) to distinguish between homogeneous and differentiated goods, as in Nunn (2007). Rauch classifies products into three categories: Those sold on organized exchange markets, products that are reference-priced, and all other products that are labeled "differentiated". I code these prod- 
ucts as 0 for products traded on organized exchanges and reference-priced products, and 1 for differentiated products. I then use product-industry concordance tables to translate this measure into an average degree of differentiation at the level of three-digit NAICS manufacturing industries. ${ }^{19}$ The industry measure is lowest for Petroleum and Coal Products (0.12), Primary Metal Manufacturing (0.14) and Paper Manufacturing (0.19), and highest for Transportation Equipment, Furniture, Apparel, and Printing (all with a score of 1). I then consider the following specification:

$$
d \log \left(Y_{i}^{k}\right)=\beta_{0}+\beta_{1} \cdot T D S_{i}^{k}+\beta_{2} \cdot T D S_{i}^{k} \cdot \operatorname{Diff}^{k}+\gamma_{i}+\alpha_{k}+\epsilon_{i}^{k}
$$

where Diff ${ }^{k}$ denotes the product differentiation measure and $Y_{i}^{k}$ stands for either employment or the total wage bill. Results are in table 11. The first two columns show results for employment growth, and columns 3-4 focus on growth of labor income. All regressions indicate that the employment decline is driven by industries producing more differentiated products.

\subsection{County-level}

In this section, I employ a different piece of variation in the data to identify the causal effect of trade relationships on employment outcomes during the crisis. For this, I compare counties within a state by their employment structure. I assume that a given industry in a state has the same trading pattern, regardless of the county in which it is located. I then construct a measure of the trade demand shock at the county-level, whose only variation within-state is coming from differences in specialization patterns across counties:

$$
\operatorname{TDSCOUNTY}_{c}=\sum_{k} \frac{L_{c}^{k}}{L_{c}^{T}}\left[\sum_{n} \frac{X_{n c}^{k}}{Y_{c}^{k}} \operatorname{Lev06}_{n}\right]
$$

This allows me to compare employment growth among counties for tradable and non-tradable industries. ${ }^{20}$ To the extent that the demand shock to tradables propagates in the local economy (through lower employment and income), we might also expect effects on employment growth in nontradable industries. I consider the following specification:

$$
\mathrm{d} \log \left(Y_{c}\right)=\beta_{0}+\beta_{1} \cdot \operatorname{TDSCOUNTY}_{c}+\beta_{2} \cdot \text { Leverage }_{c}+\alpha_{s}+\epsilon_{c}
$$

\footnotetext{
${ }^{19}$ I use both the liberal and the conservative classification of Rauch's measure and find that the results hardly differ.

${ }^{20}$ I define tradable industries as manufacturing and wholesale, and nontradable industries as all other industries except for the few remaining industries that also have recorded shipments in the CFS.
} 
where $\mathrm{d} \log \left(Y_{c}\right)$ denotes either employment growth in tradable or in nontradable industries and $\alpha_{s}$ denotes a state fixed effect. Following Mian and Sufi (2011b) I also include countylevel pre-crisis leverage ratios in the estimation to control for the local demand shock. Tables 12 and 13 show the results using the CBP data. There is a significant effect of the countylevel trade demand shock on employment growth in tradable industries, but no evidence of any further propagation in the local economy.

\section{Credit Channel Strategy and Results}

An alternative mechanism for transmitting the crisis across space is the credit channel: Following the housing bust, troubles in national financial markets may have forced banks to cut lending to firms. This section tests explicitly for the role of the credit channel in spreading the crisis across space, exploiting variation across counties in pre-crisis market shares of banks. The results do not show a significant role for the credit channel, but also cannot exclude a medium-sized effect. At the same time, results on the trade channel remain unchanged.

Starting in mid-2007, there has been increased uncertainty about asset values on banks' balance sheets. Following the subprime mortgage crisis, liquidity in the asset-backed commercial paper market started to dry up in the fall of 2007. Around the same time, the TED spread started to increase and banks increasingly faced funding problems. ${ }^{21}$ Due to the trouble in national funding markets, banks may have cut their lending to firms. The integrated national funding market for banks may thus have been another source for spreading the crisis across space.

Several papers have documented a contraction in new lending during the 2007-09 period. For instance, Ivashina and Scharfstein (2010) show that new loans to large borrowers fell by $79 \%$ between the second quarter of 2007 and the fourth quarter of 2008 in their sample of syndicated loans. Naturally, a reduction in new lending can be a result of either a fall in credit demand or in credit supply.

At least part of this contraction in new lending may be due to reduced credit supply. This is suggested by several papers that study the determinants of crisis lending growth at the bank level. For instance, Gozzi and Goetz (2010) find that banks that depended more on wholesale funding cut their lending by more during the crisis period. Likewise, Cornett et al. (2011) report that banks that held more illiquid assets on their balance sheets were more likely to reduce lending.

To study the role of credit supply shocks on economic outcomes, I make use of cross-

${ }^{21} \mathrm{~A}$ detailed documentation of events can be found in, for example, Brunnermeier (2009). 
sectional differences across counties in the composition of local banks. This strategy assumes that firms borrow funds to a large extent from local banks, i.e. banks that operate branches in the county a firm is located in. This claim finds support in the literature: Although existing literature indicates that the role of distance for business lending has fallen over the last decades, it still seems to play a significant role. For instance, although Petersen and Rajan (2002) report that over the period 1973-1993 the average borrower-lender distance has declined, the median distance in 1993 still remains very low (5 miles). In more recent work, Brevoort et al. (2010) study data until 2003, and find that there was only a modest increase in distance over this period. Moreover, they report that the trend of growing borrower-lender distance has come to a halt in the second half of their study period (1998-2003). Overall, they conclude that "distance still matters".

The analysis in this part is related to papers by Gozzi and Goetz (2010) and Greenstone and Mas (2012). In contrast to Gozzi and Goetz (2010), I do not match local economies to banks by the bank's headquarter. Instead, I use the network of bank branches to measure banks' market shares in counties. In using bank branch data, my work also differs from the paper by Greenstone and Mas (2012). These authors focus on small business lending (firms with less than $\$ 1$ million revenue) and use lending data from the community reinvestment act. They separate credit supply from demand shocks by decomposing bank-county lending growth into a county part and a bank part. While the first measures credit demand shocks, the latter captures shocks to credit supply. I take a different approach to the identification problem by relying on variation in lending growth across banks based on differences in pre-crisis exposure to troubles in national financial markets. My work thus differs from Greenstone and Mas (2012) by making use of a specific supply shock to banks.

\subsection{Empirical Strategy}

The main challenge for this empirical part is to separate the effect of a credit supply shock from a reduction in loan demand that may happen at the same time. The empirical strategy relies on using (i) variation in lending growth across banks that is due to different ex-ante exposure of banks to distress in national financial markets, and (ii) variation across counties in pre-crisis market shares of banks.

In order to control specifically for a credit supply shock, I consider the following specification:

$$
d \log \left(Y_{c}\right)=\beta_{0}+\beta_{1} \text { TDSCOUNTY }_{c}+\beta_{2} \text { Leverage }_{c}+\beta_{3}{\text { Loan } \text { Growth }_{c}+\alpha_{s}+\epsilon_{c}}
$$

The left hand side measures 2007-09 employment growth in county $c, \alpha_{s}$ denotes a state 


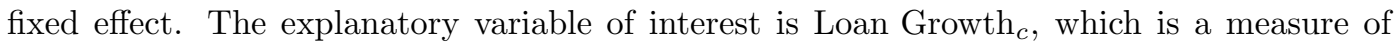
the 2007-09 growth of outstanding commercial and industrial loans at the county level. It is defined as the weighted average of loan growth of banks that own branches in that county:

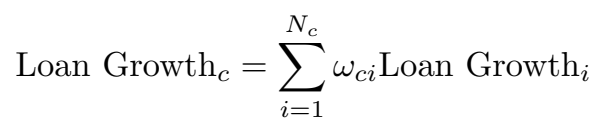

where $N_{c}$ is the number of banks that own branches in county $c$ and $\omega_{c i}$ is a measure of the market share of bank $i$ in that county. Given that I do not have data on bank lending by county, I measure the market share as the share of deposits held by branches of bank $i$ in county $c$ in total deposits in county $c$.

Equation 6 presents an endogeneity concern: Shocks other than a credit supply shock may reduce employment growth in a county, leading to a reduction in loan demand and the stock of outstanding loans. I take two complementary approaches to mitigate endogeneity concerns. First, I focus only on counties that are dominated by large banks. For these counties, it is much less likely that loan growth of banks depends on county-level outcomes. Second, I use variation in loan growth of banks due to different pre-crisis exposure to troubles in national financial markets in a two-stage-least-squares setup.

\subsection{Data}

I use data from two sources to construct a measure of a credit supply shock at the county level. First, I use data on the bank branch network from the FDIC to construct a measure of bank pre-crisis (2007) market shares at the county level. These data give me information about the universe of bank branches in the U.S.. In particular, I use information on the location of the branch (county and state), the identity of the bank owning the branch, and the amount of deposits in the branch. I delete all branches of banks that do not file Call reports ${ }^{22}$, all branches that do not offer full services (like drive-through facilities, administrative offices, etc.), and branches of banks that specialize in activities other than commercial lending (i.e. agriculture, credit cards, mortgages, consumer lending, and other specializations).

I then match these data with bank financial information from the Call Reports. In order to account for potential risk sharing across banks within the same holding company, I aggregate banks to the bank-holding-company (BHC) level. Finally, to avoid changes in balance sheet variables that are due to M\&As as opposed to the banks normal operations, I delete all banks that were engaged in M\&As across different bank holding companies. The final bank branch dataset consists of 43,000 branches belonging to 6,300 banks (or bank

\footnotetext{
${ }^{22}$ Prior to 2012, Office of Thrift Supervision (now OCC) institutions filed a quarterly Thrift Financial Report. All other institutions in the data file the Call report.
} 
holding companies). I then collapse it to the county level.

At the county-level, there is large variation in loan growth, even after accounting for state fixed effects. For illustration, figure 10 shows a histogram of county-level loan growth, demeaned at the state level.

\subsection{Results}

\section{Least Squares}

I start by presenting ordinary least squares results for equation 6 . I estimate equation 6 separately for employment growth in tradables and nontradables. I present results for two separate measures of loan growth, one using only commercial and industrial loans on the balance sheet, while the other also includes open lines of credit. Table 14 shows the results. The coefficient on the trade variable is still negative and different from zero, and very similar in magnitude to the previous estimations at the county level. The results on the credit channel are inconclusive. While some specifications hint at a positive relationship between loan growth and employment growth, standard errors are large. In particular, I cannot exclude a modest positive relationship between loan growth and employment growth.

\section{Counties Dominated by Large Banks}

A potential concern with the previous results is a reverse causality problem: Loan growth at the bank-level is endogenous to demand at the county level. In particular, this should be true for small banks which are only active lenders in very few counties. One way to reduce this endogeneity concern, therefore, is to restrict attention to counties that are dominated by large banks. In the next set of estimations, I therefore focus on counties in which large banks (defined as being in the top $10 \%$ of the asset size distribution) have a joint market share of more than $50 \%$. This roughly reduces the sample of counties by half. Due to the size of these banks, it is unlikely that their loan growth is determined by economic conditions in a particular county. ${ }^{23}$

Results for this estimation are in table 15 and are very similar to the ones obtained from the total sample. Most importantly, the coefficient on the trade variable again remains unchanged.

\footnotetext{
${ }^{23}$ Results are very similar if I sort banks by the number of counties in which they operate branches, instead of asset size.
} 


\section{Instrumental Variable Estimations}

A second approach to mitigate endogeneity concerns is to an instrumental variable strategy. In particular, the idea is to use variation in loan growth across banks that comes from different pre-crisis exposure to funding problems. In particular, I use pre-crisis values of the share of illiquid assets in total assets, the share of non-core liabilities in total assets, and the share of nonperforming loans in total loans as instruments. ${ }^{24}$ To measure the share of noncore financing, I follow Gozzi and Goetz (2010). The variable captures a bank's reliance on wholesale deposits and on non-deposit financing sources such as repos and interbank loans. I compute the share of illiquid assets in total assets as in Cornett et al. (2011). ${ }^{25}$ Finally, non-performing loans are defined as loans 90 days or more past due plus non-accruing loans. I aggregate these variables to the county level again using deposit weights.

The exclusion restriction may be violated if bank portfolios are also endogenous to local economic outcomes. One particular concern may be that some banks depend more on wholesale financing because local deposit supply in their locations is low. Low local deposit supply may in turn be correlated with economic outcomes, for instance through consumer indebtedness and reductions in consumption. Table 16 shows correlations of the instruments with the county-level deposit-to-employment ratio, showing no significant correlation between instruments and local deposit holdings. The table does, however, show correlations between the instruments and the pre-crisis construction share, which is why this variable is added as a control.

The first stage delivers the expected negative signs for all three measures of bank-level vulnerability, and an F-statistic of 9 . Table 17 presents the results on the second stage. It shows that the results for the trade channel are robust to this exercise. In contrast, the table shows no significant effect of the credit channel, but again standard errors for this estimate are relatively large.

\section{Model}

This section presents a model of the diffusion of the crisis through trade. The reduced form empirical estimates only allow me to econometrically identify the relative effect of the trade channel on industry outcomes. It does not allow me to capture the part of the trade channel

\footnotetext{
${ }^{24}$ Alternative measures that have been proposed in the literature are the capital ratio and a measure for offbalance sheet commitments. I find that the capital ratio does not have much explanatory power for loan growth, and that off-balance sheet commitments are highly positively correlated with the measure of non-core financing. I thus exclude these two variables.

${ }^{25}$ Specifically, illiquid assets are given by the sum of loans and leases net of unearned income, and MBS and ABS securities (held-to-maturity and available for sale).
} 
that affects all industries in the same state (this part of the trade channel is absorbed by the state fixed effect). How important was the trade channel for the total spread of the crisis? Answering this question is the primary purpose of the model. Moreover, the model allows me to discuss the role of general equilibrium effects and to give a better structural understanding of the empirical results.

In the model, a decline in the dividend of a real asset causes a collapse in expenditure, and a fall in the asset value. An asset in the model is a tree that produces a stochastic dividend (an outside good), which is freely tradable. I think of this outside sector as a reduced form way of modeling the credit and expenditure dynamics related to housing: Prior to the recession, households in states with housing booms financed increasing expenditure through home equity withdrawals (Mian and Sufi, 2011a). At the onset of the recession, this housingfinanced expenditure boom reversed, and households had to cut on consumption during the deleveraging process. The model parsimoniously captures these expenditure dynamics related to housing by letting the dividend of the outside sector vary over time. When the dividend in state $i$ is high, total expenditure rises, and the state runs a trade deficit in manufacturing financed by the outside good. The fall in expenditure at the onset of the recession is captured by a drop in the dividend, reducing the manufacturing trade deficit in states with housing boom-bust cycles. The advantage of this modeling strategy is that it allows me to focus on the heterogeneity in trade linkages and the spread of the crisis across space, taking the expenditure dynamics generated by the housing cycle as given.

The model thus abstracts from the existence of borrowing and lending across states, because I focus on the diffusion of the expenditure decline through the economy. Instead of studying the link between the initial shock and expenditure (which would require a model focusing more on intertemporal borrowing and lending), I instead focus on the connection between the expenditure decline and the distribution of employment and wage outcomes. To focus on this connection, I model the shock in a way that it generates a cross-sectional pattern of expenditure growth as observed in the data.

\subsection{Setup}

There are $N$ states denoted by $i=1, \ldots, N$, each populated by a representative household that supplies labor and consumes. The only storage for wealth are $N$ "housing" trees. The tree in state $i$ pays income $Z_{i t}$ in the form of a freely tradable outside consumption good whose price is normalized to one. Since housing is largely locally owned, I assume that the household in state $i$ owns $100 \%$ of the housing tree in state $i{ }^{26}$ As a result of this

\footnotetext{
${ }^{26}$ One can consider alternative ownership structures. The results will continue to hold if portfolio shares are heterogeneous across states, so that there is ex-ante different exposure to wealth shocks. What matters for the
} 
assumption, it does not matter whether dividends are stochastic or deterministic.

The interest rate faced by households in state $i$ is then given by

$$
\left(1+r_{i t+1}\right) V_{i t}=Z_{i t+1}+V_{i t+1}
$$

where $V_{i t}$ s the value of tree $i$ at the end of period $t$.

\section{Households}

The household chooses consumption and labor services to maximize expected utility

$$
E_{0}\left[\sum_{t=1}^{\infty} \beta^{t} u\left(C_{i t}, L_{i t}\right)\right]
$$

subject to the household DBC:

$$
A_{i t}=\left(1+r_{i t}\right) A_{i t-1}+W_{i t} L_{i t}-P_{i t} C_{i t}
$$

Since the outside good is used as numeraire, the price of aggregate consumption, $P_{i t}$, is measured in (units of outside good/units of aggregate consumption). Let the utility function be given by

$$
u\left(C_{i t}, L_{i t}\right)=\frac{C_{i t}^{1-\gamma}}{1-\gamma}-\eta \frac{L_{i t}^{1+\frac{1}{\phi}}}{1+\frac{1}{\phi}} .
$$

It follows that the Euler Equation is:

$$
C_{i t}^{-\gamma}=\beta E_{t}\left[\left(1+r_{i t+1}\right) \frac{P_{i t}}{P_{i t+1}} C_{i t+1}^{-\gamma}\right]
$$

The tree yields a return of $1+r_{i t+1}$ from period $t$ to $t+1$ in units of the outside good. This needs to be adjusted by $\frac{P_{i t}}{P_{i t+1}}$ in order to arrive at the return in units of aggregate consumption.

Consumption: Aggregate consumption is given by a Cobb-Douglas aggregate of produced consumption goods and consumption of the outside good:

$$
C_{i t}=\left(C_{i t}^{P}\right)^{\delta}\left(C_{i t}^{O}\right)^{1-\delta}
$$

model is the cross-section in income shocks generated by the shocks to the housing trees. This set of income shocks is completely determined by the calibration strategy. With imperfect home bias, the calibration strategy would change the size of the shocks to tree dividends, so that the resulting shocks to household income are the same as with full home bias. 
Consumption of produced goods consists of tradables (also labeled manufactures) and nontradables.

$$
C_{i t}^{P}=\left(C_{i t}^{M}\right)^{\delta^{M}}\left(C_{i t}^{N}\right)^{1-\delta^{M}}
$$

Manufacturing consumption $C_{i t}^{M}$ is a composite of consumption in different manufacturing industries:

$$
C_{i t}^{M}=\prod_{k=1}^{S}\left(c_{i t}^{k}\right)^{\alpha_{i}^{k}}
$$

Within each manufacturing industry $k$, trade is modeled in an Armington-structure: Each state produces a unique variety of the good in industry $k$, and consumption $c_{i t}^{k}$ is a CES composite of the varieties from different origins. ${ }^{27}$

$$
c_{i t}^{k}=\left(\sum_{j}\left(\omega_{i j}^{k}\right)^{\frac{1}{\sigma}}\left(c_{i j t}^{k}\right)^{\frac{\sigma-1}{\sigma}}\right)^{\frac{\sigma}{\sigma-1}}
$$

The share of expenditure that state $i$ spends on goods form state $j$ in industry $k$ can be written as:

$$
\pi_{i j t}^{k}=\omega_{i j}^{k}\left(\frac{P_{i t}^{k}}{p_{i j t}^{k}}\right)^{\sigma-1}
$$

Labor Supply and Wages: Workers can supply labor in the tradable and nontradable sector, and in different industries within the tradable sector. However, the labor market is subject to two frictions: Labor mobility frictions prevents wage equalization across sectors and industries, and there is rigidity in the adjustment of real wages. I introduce labor mobility frictions in the model in order to account for the different evolution of wages across industries in a state, as shown in the empirical part. I allow the these frictions to vary for inter-sectoral mobility (manufacturing vs. nontradables) and intra-sectoral mobility (across industries within manufacturing). Wage stickiness is added to allow for equilibrium unemployment and to improve realism of the quantitative exercise.

Aggregate labor is a CES composite of labor services in manufacturing and nontradables:

$$
L_{i t}=\left(\left(L_{i t}^{M}\right)^{\frac{1+\rho}{\rho}}+\left(L_{i t}^{N}\right)^{\frac{1+\rho}{\rho}}\right)^{\frac{\rho}{1+\rho}}
$$

where $\rho \in[0, \infty)$ measures the degree of worker mobility across sectors. The case $\rho=$ $\infty$ denotes perfect labor flexibility, under which wages equalize across the tradable and

\footnotetext{
${ }^{27}$ The particular within-industry structure that is driving trade is not crucial for the model. For instance, using an Eaton-Kortum structure for each industry would deliver the same simulation results as the present Armington structure if their comparative advantage parameter is set to the value of $\sigma-1$ in the present model.
} 
nontradable sector. Labor supply for tradables is given by supply for different industries $k$ :

$$
L_{i t}^{M}=\left(\sum_{k}\left(L_{i t}^{k}\right)^{\frac{1+\nu}{\nu}}\right)^{\frac{\nu}{1+\nu}}
$$

The parameter denoting labor immobility within the tradable sector potentially differs from labor immobility across sectors and is denoted by $\nu$. The wage in state $i$, industry $k$, is given by

$$
w_{i t}^{k}=\left(w_{i t-1}^{k}\right)^{\lambda}\left(w_{i t}^{k *}\right)^{1-\lambda}
$$

where the parameter $\lambda$ governs the degree of real wage rigidity and varies between 0 (perfect wage flexibility) and 1 (full wage rigidity). An analogous equation holds for the wage in the nontradable sector, $W_{i t}^{N}$. The variable $W_{i t}^{*}=\left(\sum_{k}\left(w_{i t}^{k *}\right)^{1+\nu}\right)^{\frac{1}{1+\nu}}$ is the wage at which workers are willing to supply an aggregate labor input $L_{i t}$, i.e. it is given by the marginal rate of substitution:

$$
\eta \frac{L_{i t}^{\frac{1}{\phi}}}{C_{i t}^{-\gamma}}=\frac{W_{i t}^{*}}{P_{i t}}
$$

Labor supply across industries follows the rule:

$$
L_{i t}^{k}=\left(\frac{w_{i t}^{k *}}{W_{i t}^{*}}\right)^{\nu} L_{i t}
$$

and the aggregate wage solves:

$$
W_{i t} L_{i t}=\sum_{k} w_{i t}^{k} L_{i t}^{k}
$$

\section{Firms}

In each industry and state, there are many identical firms that face perfectly competitive output and labor markets within their industry. Firms hire workers in the local labor market and produce output with a constant returns technology. ${ }^{28}$

$$
Q_{i t}^{k}=A_{i}^{k} L_{i t}^{k}
$$

so that sales $Y_{i t}^{k} \equiv p_{i t}^{k} Q_{i t}^{k}$ equal earnings $w_{i t}^{k} L_{i t}^{k}$. Again, analogous expressions hold for the nontradable sector.

Shipments are subject to iceberg transportation $\operatorname{costs} \tau_{n i}^{k}$, so that the price $p_{n i t}^{k}$ can be written as $p_{n i t}^{k}=\tau_{n i}^{k} \frac{w_{i t}^{k}}{A_{i}^{k}}$.

\footnotetext{
${ }^{28}$ All model implications remain unchanged if I assume decreasing returns to labor (with constant elasticity) and that firms are owned locally. In that case, earnings growth still equals sales growth. The only difference is that total income growth is divided into profit growth and growth in earnings (which would be the same).
} 


\section{Equilibrium}

An equilibrium is an allocation (labor services, production and consumption) and prices (output prices and wages) such that (i) households optimize, (ii) firms optimize, and (iii) markets clear. In equilibrium, total expenditure by households in state $i$ equal the sum of income and the asset's dividend:

$$
X_{i t}=W_{i t} L_{i t}+Z_{i t}
$$

and household wealth equals the value of the domestic asset: $A_{i t}=V_{i t}$. Expenditure on manufacturing goods are a constant fraction of total expenditure

$$
X_{i t}^{M}=\delta^{M} \delta\left(W_{i t} L_{i t}+Z_{i t}\right)
$$

so that a state runs a trade deficit whenever the dividend $Z_{i t}$ is high. Wages in manufacturing industries are determined in the trade equilibrium,

$$
w_{i t}^{k} L_{i t}^{k}=\delta^{M} \delta \sum_{n} \pi_{n i t}^{k} \alpha_{n}^{k}\left(W_{n t} L_{n t}+Z_{n t}\right)
$$

and trade flows have a structural gravity representation as defined in Head and Mayer (2013):

$$
X_{n i}^{k}=\frac{Y_{i}^{k}}{\Omega_{i}^{k}} \frac{X_{n}^{k}}{\left(P_{n}^{k}\right)^{1-\sigma}} \omega_{n i}^{k}\left(\tau_{n i}^{k}\right)^{1-\sigma},
$$

where $\Omega_{i}^{k}$ is given by $\Omega_{i}^{k}=\sum_{n} \omega_{n i}^{k}\left(\frac{\tau_{n i}^{k}}{P_{n}^{k}}\right)^{1-\sigma} X_{n}^{k}$.

Total income in the economy is tied down by the supply of the outside good:

$$
\sum_{i} W_{i t} L_{i t}=\frac{\delta}{1-\delta} \sum_{i} Z_{i t}
$$

Finally, the value of asset $i$ at time $t$ can be found by iterating on the Euler equation:

$$
V_{i t}=E_{t}\left[\sum_{j=1}^{\infty} \beta^{j}\left(\frac{C_{i t+j}}{C_{i t}}\right)^{-\gamma}\left(\frac{P_{i t}}{P_{i t+j}}\right) Z_{i t+j}\right]
$$

\subsection{Solution and Calibration}

To analyze the role of the trade channel for the transmission of shocks, I study the model's response to a shock in dividends $Z$. In the model, a reduction in the dividend $Z_{i}$ for state $i$ reduces total expenditure, including expenditure on manufactured goods. It therefore leads 
to lower demand for producers selling to state $i$. At the same time, it has no direct effect on production in state $i$, but only indirect effects through general equilibrium adjustments.

In general equilibrium, wages and prices will respond. In particular, a reduction in demand for an industry's product exerts downward pressure on wages. In a labor market with perfect worker mobility across industries, we should see only differential employment growth, but not differential wage growth across industries. Yet we observe differential wage growth empirically. The model allows for this possibility by introducing imperfect labor mobility across industries. While there is reallocation of employment to other industries and potentially to the nontradable sector, total employment changes as well through endogenous labor supply.

\section{Identifying Labor Mobility Parameters}

The parameters $\nu$ and $\rho$ determine how easily labor can shift between manufacturing industries, and between the tradable and nontradable sector, respectively. They can take on values between zero (labor completely immobile) and infinity (perfect mobility). The parameters can also be interpreted as elasticities of labor supply to individual manufacturing industries and to the tradable and nontradable sector, respectively.

I identify the the parameter governing labor mobility frictions across manufacturing industries from the reduced form estimates. The parameter $\nu$ measures this degree of labor mobility frictions, where a larger $\nu$ means a higher degree of mobility. The model implies that the parameter can be identified directly from the reduced form estimations on employment and average wages. Writing the labor allocation rule of households in growth rates delivers the following equation: ${ }^{29}$

$$
\hat{L}_{i}^{k}=\frac{\nu}{1-\lambda}\left(\hat{w}_{i}^{k}-\hat{W}_{i}^{M}\right)+\hat{L}_{i}^{M}
$$

That is, conditional on a state fixed effect, employment and wage growth are directly proportional. This allows me to identify $\frac{\nu}{1-\lambda}$ as the ratio of coefficients on the trade demand shock from the employment and wage regressions. ${ }^{30}$ I use the preferred estimates of these coefficients from the weighted least squares regressions using only manufacturing industries

(Table 4 columns 2 and 6) and obtain

$$
\frac{\nu}{1-\lambda}=\frac{\hat{\beta}_{1}^{L}}{\hat{\beta}_{1}^{w}}=3
$$

\footnotetext{
${ }^{29} \mathrm{I}$ assume that the economy starts from a state with no endogenous wage dynamics, i.e. $w_{i t-1}^{k}=w_{i t-1}^{k *}$. This implies that the growth rate of wages is a fixed share of the growth rate of the MRS: $\hat{w}_{i t}^{k}=(1-\lambda) \hat{w}_{i t}^{k *}$.

${ }^{30}$ Subtracting state and industry fixed effects, we can write the regression equation for employment growth as $\tilde{\hat{L}}_{i}^{k}=\beta_{0}^{L}+\beta_{1}^{L} \widetilde{\operatorname{TDS}}_{i}^{k}+\tilde{\epsilon}_{i}^{k}$, and $\tilde{\hat{L}}_{i}^{k}=\frac{\nu}{1-\lambda} \tilde{\hat{w}}_{i}^{k}$ from the model equation. It then follows that $\hat{\beta}_{1}^{L}=\frac{\nu}{1-\lambda} \hat{\beta}_{1}^{w}$.
} 
I calibrate the wage rigidity parameter following Shimer (2010) and Gorodnichenko et al. (2012) as $\lambda=0.79$, and thus infer that $\nu=0.63$.

Next, I identify the parameter $\rho$, which governs frictions to labor mobility across the tradable and nontradable sector. To identify this parameter, I restrict the model to reproduce the cross-sectional correlation between employment growth in manufacturing and nonmanufacturing at the state-level, which equals 0.55 in the data. In the model, this moment is sensitive to the labor immobility parameter between manufacturing and non-manufacturing. In particular, if $\rho=0$ (complete immobility), the correlation between manufacturing and non-manufacturing employment is one, and it is declining as $\rho$ increases. Using a simulated method of moments approach to determine this parameter delivers a value of $\rho=0.42$, implying higher rigidity between manufacturing and non-manufacturing than across manufacturing industries.

How do the parameter values inferred from the data compare to the literature? Ashenfelter et al. (2010) review several studies from the micro literature that estimate the labor supply elasticity faced by an individual firm. In principle, one would expect labor mobility to be higher across firms within an industry compared to mobility across different industries, for instance because of lower search frictions or more similar skill requirements. Consequently, the labor supply elasticity faced by individual firms is likely higher than the elasticity faced by an industry. The studies reviewed by Ashenfelter et al. (2010) estimate very low shortrun labor supply elasticities at the firm level, in the range between 0.1 and 2, and higher long run elasticities (between 2 and 4). Considering the short-run nature of my study and that firm-level labor supply elasticities are most likely upper bounds for industry-level labor supply elasticities, my estimates for $\nu$ and $\rho$ seem reasonable.

\section{Calibration}

In addition to the parameters above, I need to make choices for other model parameters. I set both the coefficient of relative risk aversion, $\gamma$ and the labor supply elasticity, $\phi$, equal to 2. These values are in line with existing literature. Next, I need to specify values for $\delta$, the share of produced goods and services in expenditure, and $\delta^{M}$, the share of manufactured goods among produced goods. I set the value for $\delta$ equal to 0.8 , which matches a share of consumer expenditure on housing (i.e. shelter) equal to $20 \%$, as found in the consumer expenditure survey and in, for example, Piazzesi et al. (2007). The value for $\delta^{M}$ is set to 0.18 as in Eaton et al. (2011), and $g$ is set to -0.044 to roughly match the decline of real GDP from peak to trough during the recession. Instead of calibrating trade parameters $\tau_{n i}^{k}$ and $\omega_{n i}^{k}$, I plug observed trade shares $\pi_{n i}^{k}$ directly into the model, following the work by Dekle et al. (2007). Finally, I calibrate the consumption parameters $\alpha_{i}^{k}$ to match the expenditure 
shares observed in the trade data.

\section{Modeling the Shock}

The model asks what share of the spread of the crisis can be explained by the diffusion of the consumer demand shocks at the beginning of the recession. I therefore think of the shocks in the model, $d Z_{i}$, as being directly related to household leverage. To pin down this relationship, I employ a simulated method of moments approach: In general equilibrium, I require that the model can reproduce exactly the same regression relationship between expenditure growth and pre-crisis leverage that has been identified by Mian et al. (2012).

Since expenditure growth in the model can be expressed as $\hat{X}_{i}=\frac{Y_{i}}{X_{i}} \hat{Y}_{i}+\frac{d Z_{i}}{X_{i}}$, I start by requiring that $\frac{d Z_{i}}{X_{i}}$ is linear in leverage, i.e. $\frac{d Z_{i}}{X_{i}}=a+b \cdot L e v_{i}$. The parameter $a$ can be expressed as a function of the growth rate of aggregate expenditure, $g$. This delivers $a=g(1-\delta)-b \sum_{i} \frac{X_{i}}{X} \operatorname{Lev}_{i}$. The parameter $b$ is determined in a simulated method of moments procedure: After general equilibrium adjustments, the model reproduces the Mian et al. (2012) regression relationship between expenditure growth and leverage at the state level. That is, $b$ is implicitly determined through the relationship $\frac{\operatorname{Cov}\left(\hat{X}_{i}, \operatorname{Lev}_{i}\right)}{\operatorname{Var}\left(\operatorname{Lev}_{i}\right)}=\chi$, where $\chi$ denotes the coefficient on household leverage in Mian et al. (2012). Notice that this approach does not require expenditure growth to be exactly linear in leverage: A state that sells relatively more to high-leverage states will experience lower income growth, and therefore be below the regression line. Mian et al. (2012) estimate the effect of household leverage on consumer expenditure for four different spending categories. In particular, their results differ among durable and non-durable consumption goods. To arrive at a single statistic summarizing the effect of household leverage on expenditure growth, I first take simple averages of their coefficients within the durable and nondurable category, and then aggregate the two effects using employment weights for durable and nondurable manufacturing. ${ }^{31}$ Using this procedure, I arrive at a coefficient of $\chi=-0.11$.

\subsection{Interpreting the Empirical Results}

Decomposing earnings growth in the model delivers an equation that is similar to the one written down in the empirical part. Comparing this model equation to the empirical specification helps in interpreting the empirical results.

\footnotetext{
${ }^{31}$ I use the U.S. Census definitions of durable and nondurable manufacturing to sort manufacturing industries into these categories.
} 
In the model, earnings growth can be written as follows

$$
\hat{Y}_{i}^{k}=\sum_{n} \frac{X_{n i}^{k}}{Y_{i}^{k}}\left(\hat{\pi}_{n i}^{k}+\hat{X}_{n}\right)
$$

The variable $\hat{\pi}_{n i}^{k}$ is the change in the market share by industry $k$, located in state $i$, in market $n$. The changes in the market share are driven by changes in factor costs:

$$
\hat{\pi}_{n i}^{k}=(\sigma-1)\left(\sum_{j=1}^{N} \pi_{n j}^{k} \hat{w}_{j}^{k}-\hat{w}_{i}^{k}\right)
$$

The market share of industry $k$ from state $i$ in market $n$ rises, if its factor cost fall by more than the factor cost of its competitors in market $n$. Given a relative fall in factor costs, the market share rises relatively more for industries selling more substitutable products. Aggregating over all markets $n, \sum_{n} \frac{X_{n i}^{k}}{Y_{i}^{k}} \hat{\pi}_{n i}^{k}$ measures the change in earnings driven by changes in competitiveness.

The expression $\sum_{n} \frac{X_{n i}^{k}}{Y_{i}^{k}} \hat{X}_{n}$ measures a demand effect: Because total expenditure in destination $n$ collapses, earnings of the producers fall. This effect includes both a direct effect through the shock $d Z_{n}$ as well as the change in income at destination $n$.

Using the fact that the normalized shock, $\frac{d Z_{n}}{X_{n}}$ is linear in leverage, we can write earnings growth and employment growth as follows:

$$
\tilde{\hat{Y}}_{i}^{k}=\theta+b \cdot{\widetilde{\operatorname{TDS}_{i}}}^{k}+\widetilde{\mathrm{GE}}_{i}^{k}
$$

where the tilde denotes that variables are written as net of state and industry fixed effects. General equilibrium effects $G E_{i}^{k}$ can be written as the sum of two terms:

$$
\mathrm{GE}_{i}^{k}=\underbrace{\sum_{n} \frac{X_{n i}^{k}}{Y_{i}^{k}} \frac{Y_{n}}{X_{n}} \hat{Y}_{n}}_{\text {Income }}+\underbrace{\sum_{n} \frac{X_{n i}^{k}}{Y_{i}^{k}} \hat{\pi}_{n i}^{k}}_{\text {Competitiveness }}
$$

An exogenous shock affects expenditure directly, and indirectly through income changes. It also changes competitiveness through changes in factor costs of industries.

In the model, the trade demand shock has a partial equilibrium effect $(b)$ and a general equilibrium effect on industry outcomes. However, when taking the model to the data we can only estimate the total effect of the trade demand shock. This is the way the equation was estimated in the empirical part. Controlling for general equilibrium effects would not be appropriate, since the general equilibrium effects are themselves outcomes of the trade demand shock. This is a typical case of a bad control. The estimations in the empirical part 
are reduced form equations.

I now compare the magnitude of the estimated effect from the data to the one predicted by the model. Solving for the response of the model to the shock provides me with modelimplied data on employment growth and wage growth for manufacturing industries at the state level. I use this new data series to re-run the reduced form estimations from the empirical part. Results for this set of regressions are in table 19.

Overall, the magnitude of the coefficients is broadly consistent with the empirical findings. The coefficients using the model-implied data are roughly $25 \%$ smaller than the results using the actual data. Note that the model parameters only pin down the relative size of the estimated coefficients, but not their absolute size. In particular, the relative size between the coefficients in the employment and wage regression is determined by the choice of the labor mobility parameter $\nu{ }^{32}$ However, the absolute size of the coefficients is not determined through the choice of model parameters. It is rather a result of the interaction between the shocks $d Z_{i}$ and the trade shares $\pi_{n i}^{k}$ that I take from the data.

How important are general equilibrium effects for these results? Estimating the parameter $b$ (the partial equilibrium effect associated with the exposure to demand shocks) via a simulated method of moments gives a value of -0.035 . Given a coefficient equal to -0.098 in the earnings equation suggests that roughly two thirds of the effect can be attributed to general equilibrium adjustments through changes in income and competitiveness.

\subsection{The Role of Trade in the Spread of the Crisis}

To assess the role of trade in spreading the crisis across space, I ask: What would have been the distribution of the crisis across space in a world without trade? To that end, I compute the model's response if each state was a closed economy. I define the spread of the crisis as the difference between the closed economy model and the data. I then gauge the contribution of trade to the spread of the crisis by asking how much closer the trade model, compared to the closed economy model, is to the data.

\section{The Closed Economy Case}

I first compute the response if each state was a closed economy. That is, I use the shocks $d Z_{i}$ and compute the model's response if each state $i$ was in autarky, using the same model parameters as before (except the trade parameters). Computing the state-level one-period

\footnotetext{
${ }^{32}$ Of course, this also pins down the size of these coefficients relative to the earnings regression. Since $\hat{Y}_{i}^{k}=$ $\hat{W}_{i}^{k}+\hat{L}_{i}^{k}$, we must have $\hat{\beta}_{1}^{Y}=\hat{\beta}_{1}^{w}+\hat{\beta}_{1}^{L}$.
} 
employment response in the closed economy case delivers the following equation:

$$
\hat{L}_{i}^{\text {Closed }}=\frac{\frac{1}{1-\lambda}+\delta(\gamma-1)-\gamma}{\frac{1}{1-\lambda}+\delta(\gamma-1)+\frac{1}{\phi}} \hat{Z}_{i}
$$

For the parameter values chosen, the employment response is procyclical. ${ }^{33}$

\section{Comparing Closed Economy, Open Economy, and Data}

I can now compare the outcomes predicted on employment growth by the closed economy model, the model featuring trade, and the data. In particular, I assess the role of trade for the spread of the crisis by comparing the distribution of employment losses across states between the trade model and the data relative to the closed economy model and the data.

Figure 11 shows a graph comparing the model predictions on state employment growth to the data. It shows regressions lines for regressions of total employment growth on leverage for each the closed economy model, open economy model, and data. Compared to the data and the open economy model, the closed economy model implies a much steeper relationship between employment growth and leverage. In the closed economy model, all of the reduction in demand is a reduction in demand for domestically produced goods. The reduction in local labor demand is thus stronger compared to the open economy model. In this setting, trade works like insurance. Part of the negative shocks to high-leverage states is absorbed by other states, making the cross-sectional relationship between employment growth and leverage flatter compared to the closed economy world.

The spread of the crisis refers to the distribution of the recession intensity across space, starting from a set of initial shocks. If there was no diffusion of initial shocks across space, employment growth in the data should be close to employment growth in the closed economy model. I therefore define the spread of the crisis as the deviation in growth at the state level between the data and the growth that would have prevailed if each state was a closed economy. Focusing on employment growth, it is written as follows:

$$
\text { Spread }=\sum_{i=1}^{N}\left|\hat{L}_{i}^{\text {Data }}-\hat{L}_{i}^{\text {Closed }}\right|
$$

That is, I take the absolute deviation of employment growth in the closed economy model from its counterpart in the data for each state $i$, and then sum across states to arrive at an

\footnotetext{
${ }^{33}$ The employment response can only be countercyclical if the numerator of the ratio is negative, since the denominator is always positive. For very high degrees of risk aversion, the employment response may be countercyclical, because the fall in consumption during a recession would make the labor supply curve shift out wide enough to more than offset the fall in labor demand.
} 
aggregate statistic.

I now compute how much of this spread is accounted for by the trade channel. Analogous to the spread, I define the trade shortfall as the difference between the open economy model and the data:

$$
\text { TradeShortfall }=\sum_{i=1}^{N}\left|\hat{L}_{i}^{\text {Data }}-\hat{L}_{i}^{\text {Open }}\right|
$$

The trade shortfall thus describes the gap between model and data that remains after accounting for the diffusion of local shocks through the trade channel.

I now ask: Compared to the closed economy model, how much closer does the trade model get to the data? I define the trade share as the fraction of the total spread that the trade channel can account for.

$$
\text { TradeShare }=1-\frac{\text { TradeShortfall }}{\text { Spread }} \approx 0.44
$$

Accounting for the trade channel can thus explain almost half of the total spread of the crisis. $^{34}$

\section{Conclusion}

This paper provides evidence that trade has contributed to the geographic spread of the Great Recession, i.e. the shift of the recession away from states with housing boom-bust cycles. Empirically, I identify the trade channel by comparing economic outcomes of industries with different shipment patterns that are located in the same state. Industries that sold relatively more to states with housing boom-bust cycles grew by more before the crisis and declined faster during 2007-09. This relative effect of the trade channel is sizable: One standard deviation in the trade demand shock explains a 3 percentage point difference in 2007-09 employment growth between industries.

To assess the aggregate role of trade for the spread of the crisis, I build a model of the crisis diffusion through trade. I then shock the model using the Mian et al. (2012) relationship between leverage and consumer expenditure. The model implies a relative effect of the trade channel that is of similar magnitude as the one found empirically. Finally, I use the model to gauge the overall contribution of trade to the spread of the crisis. I define this spread of the crisis as the difference in the distribution of the recession intensity across space between the data and a closed economy world. While the 2007-09 recession was concentrated in states with housing boom-bust cycles, the model suggests that this degree of concentration

\footnotetext{
${ }^{34}$ Results in this section hardly change when I use employment-weighted absolute distances instead of simple absolute distances.
} 
would have been much higher in the absence of trade between U.S. states. Comparing the implications of the closed economy model, the model including trade, and the data, reveals that trade is responsible for roughly half of the overall spread.

At the aggregate level, therefore, trade works like insurance: Local adverse shocks are distributed across space, thereby causing business cycle comovement. In particular, this paper suggests that trade is still important for transmitting crises across space, even within a country like the U.S., where the manufacturing share in GDP has declined for years, and is low in international comparison. Moreover, my estimates may understate the importance of trade because the available data have only flows for manufactured goods and do not have information on trade in services.

The large pre-crisis U.S. current account deficit and the particularly sharp contraction in imports during the Great Recession suggest that trade may have also played a role in the international transmission of the crisis. This may have contributed to the recession particularly in key trading partners of the U.S., such as Canada and Mexico.

Finally, developing a model that captures richer dynamics of diffusion of the crisis across space is left for future work. 


\section{References}

Ashenfelter, O. C., Farber, H., and Ransom, M. R. (2010). Labor market monopsony. Journal of Labor Economics, 28(2):203-210.

Atalay, E., Hortaçsu, A., and Syverson, C. (2012). Why do firms own production chains? University of Chicago mimeo.

Autor, D. H., Dorn, D., and Hanson, G. (2012). The china syndrome: Local labor market effects of import competition in the united states. mimeo.

Bernard, A. B., Jensen, J. B., and Schott, P. K. (2009). Importers, exporters and multinationals: A portrait of firms in the U.S. that trade goods. In Dunne, T., Jensen, J. B., and Schott, P. K., editors, Producer Dynamics: New Evidence from Micro Data, volume 1, pages 513-552. University of Chicago Press.

Brevoort, K. P., Holmes, J. A., and Wolken, J. D. (2010). Distance still matters: The information revolution in small business lending and the persistent role of location, 1993-2003. Board of Governors of the Federal Reserve System Finance and Economics Discussion Series, (08).

Brunnermeier, M. K. (2009). Deciphering the liquidity and credit crunch 2007-08. Journal of Economic Perspectives, 23(1):77-100.

Cornett, M. M., McNutt, J. J., Strahan, P. E., and Tehranian, H. (2011). Liquidity risk management and credit supply in the financial crisis. Journal of Financial Economics, 101(2):297-312.

Dekle, R., Eaton, J., and Kortum, S. (2007). Unbalanced trade. NBER Working Paper, (13035).

di Giovanni, J. and Levchenko, A. A. (2009). Trade openness and volatility. Review of Economics and Statistics, 91(3):558-585.

di Giovanni, J. and Levchenko, A. A. (2010). Putting the parts together: Trade, vertical linkages, and business cycle comovement. American Economic Journal: Macro, 2(2):95124 .

Eaton, J., Kortum, S., Neiman, B., and Romalis, J. (2011). Trade and the global recession. NBER Working Paper, (16666).

Eggertsson, G. B. and Krugman, P. (2012). Debt, deleveraging, and the liquidity trap: A Fisher-Minsky-Koo approach. Quarterly Journal of Economics, 127(3):1469-1513.

Frankel, J. A. and Rose, A. K. (1998). The endogeneity of the optimum currency area criteria. Economic Journal, 108(449):1009-1025. 
Glick, R. and Rose, A. K. (1999). Contagion and trade: Why are currency crises regional? Journal of International Money and Finance, 18:603-617.

Gorodnichenko, Y., Mendoza, E. G., and Tesar, L. L. (2012). The finnish great depression: From russia with love. The American Economic Review, 102(4):1619-1643.

Gozzi, J. C. and Goetz, M. (2010). Liquidity shocks, local banks, and economic activity: Evidence from the 2007-09 crisis. Working paper.

Greenstone, M. and Mas, A. (2012). Do credit market shocks affect the real economy? Quasi-experimental evidence from the great recession and normal economic times. MIT Working paper series, 12(27).

Head, K. and Mayer, T. (2013). Gravity equations: Workhorse, toolkit, and cookbook.

Ivashina, V. and Scharfstein, D. (2010). Bank lending during the financial crisis of 2008. Journal of Financial Economics, 97(3):319-338.

Johnson, R. C. (2013). Trade in intermediate inputs and business cycle comovement. Working paper, Dartmouth College.

Kaminsky, G. L. and Reinhart, C. M. (2000). On crisis, contagion, and confusion. Journal of International Economics, 51:145-168.

Kose, M. A. and Yi, K.-M. (2006). Can the standard international business cycle model explain the relation between trade and comovement? Journal of International Economics, 68:267-295.

Levchenko, A., Lewis, L., and Tesar, L. (2010). The collapse of international trade during the 2008-2009 crisis: In search of the smoking gun. IMF Economic Review, 58(2):214-253.

Mian, A., Rao, K., and Sufi, A. (2012). Household balance sheets, consumption, and the economic slump. UC Berkeley mimeo.

Mian, A. and Sufi, A. (2011a). House prices, home equity-based borrowing, and the U.S. household leverage crisis. American Economic Review, 101(5).

Mian, A. and Sufi, A. (2011b). What explains high unemployment? The aggregate demand channel. UC Berkeley mimeo.

Midrigan, V. and Philippon, T. (2011). Household leverage and the recession. mimeo, New York University.

Nunn, N. (2007). Relationship-specificity, incomplete contracts, and the pattern of trade. Quarterly Journal of Economics, 122(2):569-600. 
Petersen, M. and Rajan, R. (2002). Does distance still matter? The information revolution in small business lending. Journal of Finance, 57(6).

Piazzesi, M., Schneider, M., and Tuzel, S. (2007). Housing, consumption and asset pricing. Journal of Financial Economics, 83(3):531-569.

Rajan, R. and Zingales, L. (1998). Financial dependence and growth. American Economic Review, 88(3).

Rauch, J. E. (1999). Networks versus markets in international trade. Journal of International Economics, 48:7-35.

Shimer, R. (2010). Labor markets and business cycles. Princeton University Press Princeton, NJ.

van Rijckeghem, C. and Weder, B. (2001). Sources of contagion: Is it finance or trade? Journal of International Economics, 54:293-308. 
Figure 1: Yearly change in unemployment rate across US counties, 2006-07, 2007-08, and 2008-09
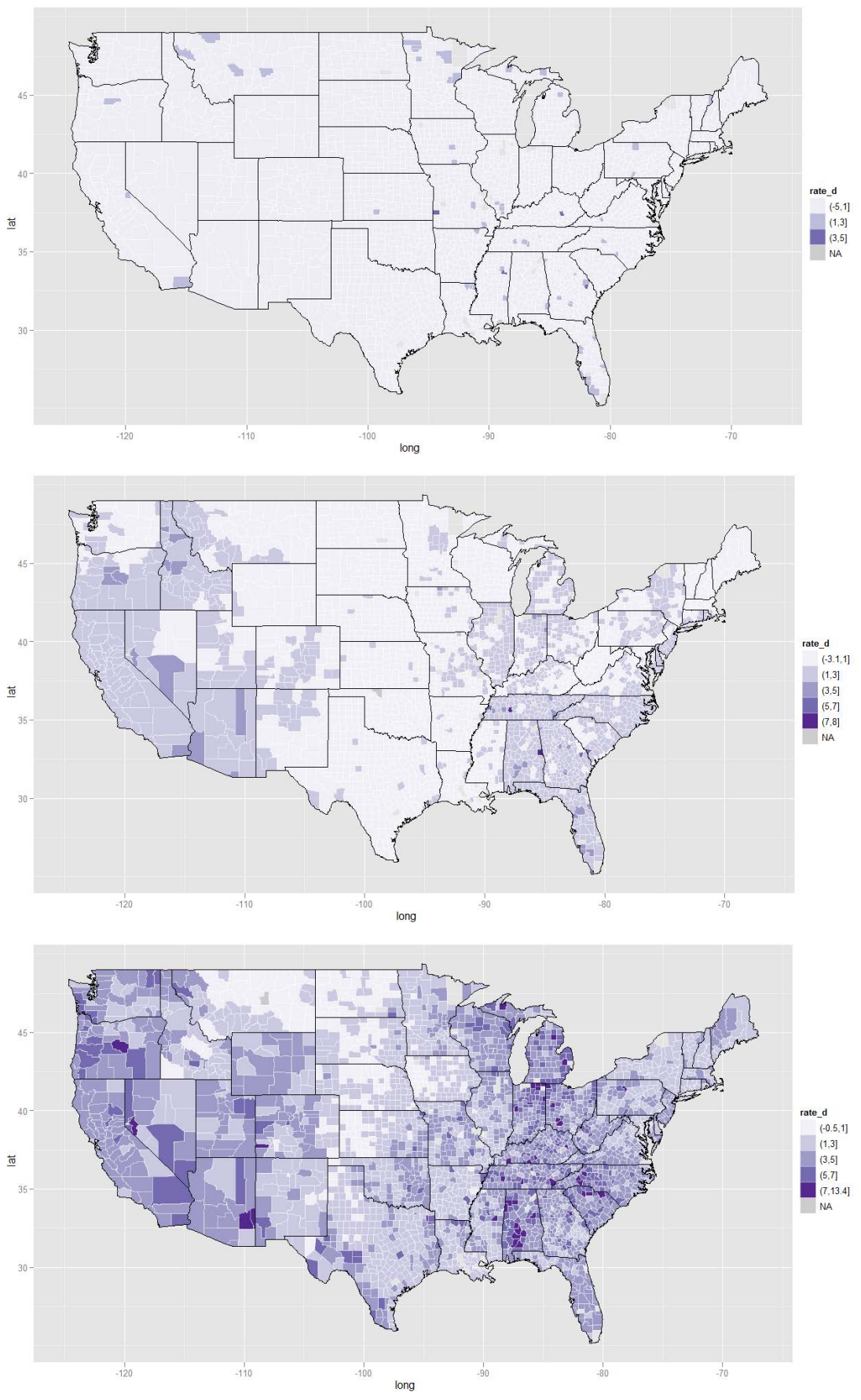

Notes: The maps show the year-on-year change in the unemployment rate from 2006-07, 2007-08, and 2008-09 across U.S. counties. Data are from the BLS. 
Figure 2: Trade Linkages vs. Distance

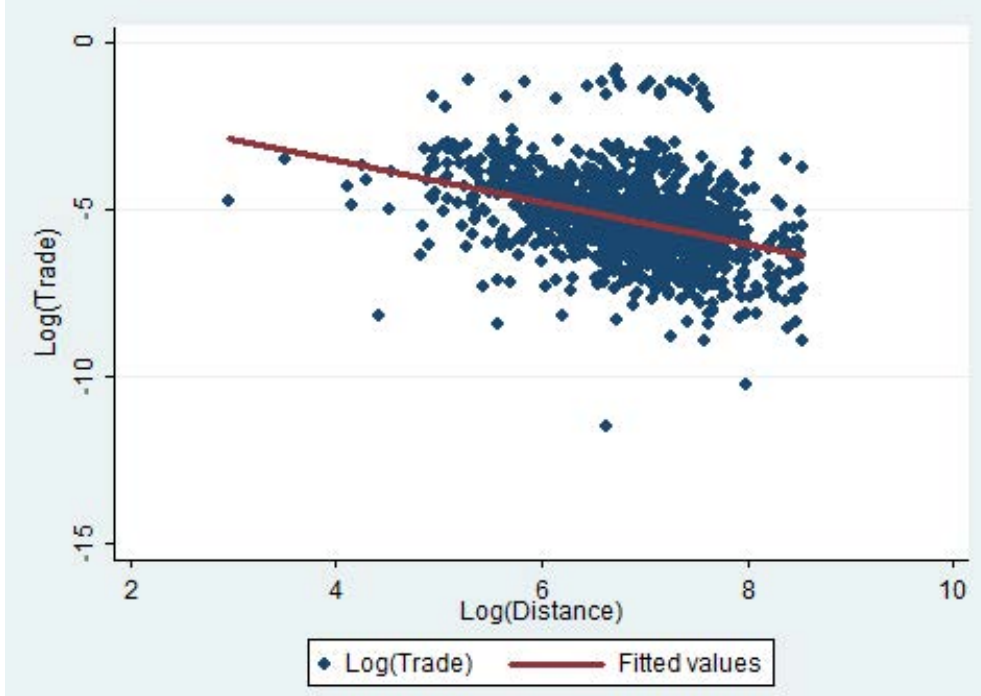

Notes: This figure plots the results from a bivariate regression of bilateral state-level trade flows on bilateral distance.

Figure 3: Transport costs drive shipment patterns across industries

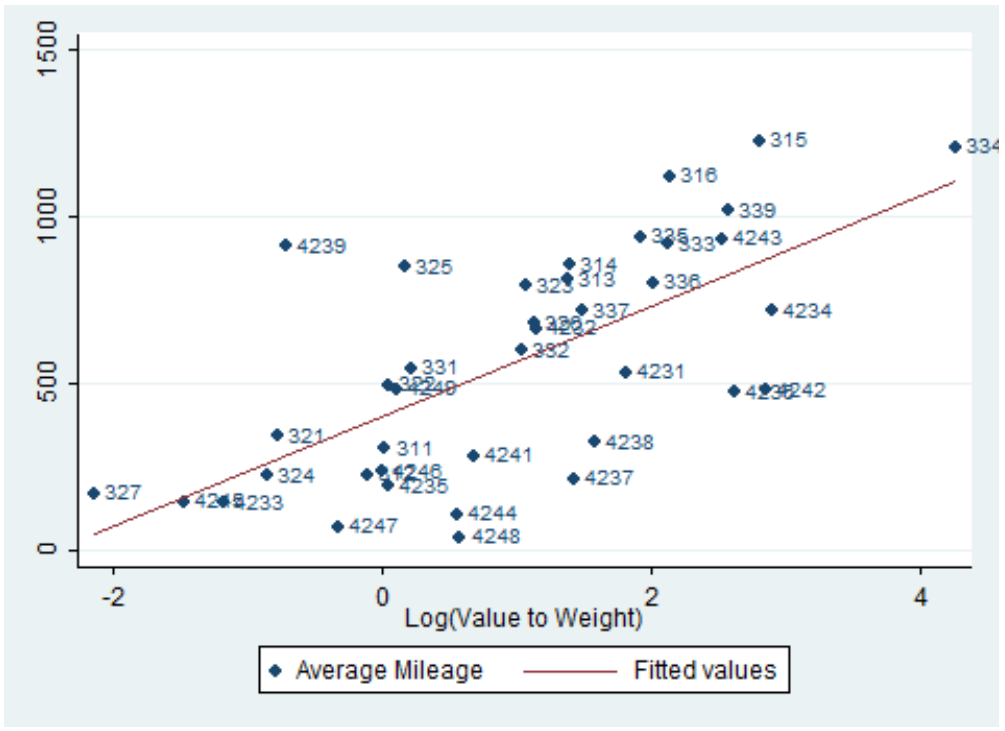

This graph shows the average mileage traveled by shipments in a particular industry, plotted against the ( $\log$ of) the ratio of total value shipped over total tonnage shipped. Data are from the 2007 round of the CFS. 
Figure 4: Intra-state heterogeneity in the trade demand shock

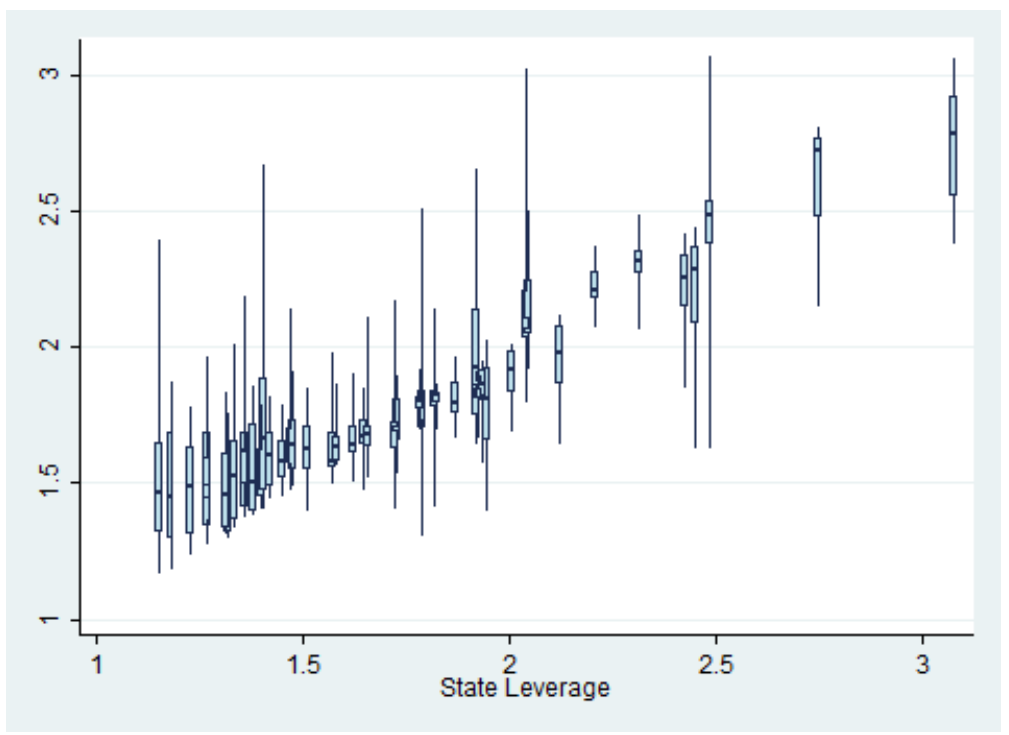

Notes:This figure shows a box plot of the trade demand shock at the state-industry level vs. state-level leverage. Each vertical bar represents one state. The thick boxes show the range of values spanned by the 25 th and 75 th percentile. The thin lines (whiskers) measure the values spanned by the 5th and 95th percentile. The most extreme values in each state are excluded.

Figure 5: State-level trade deficit vs. state-level HH leverage

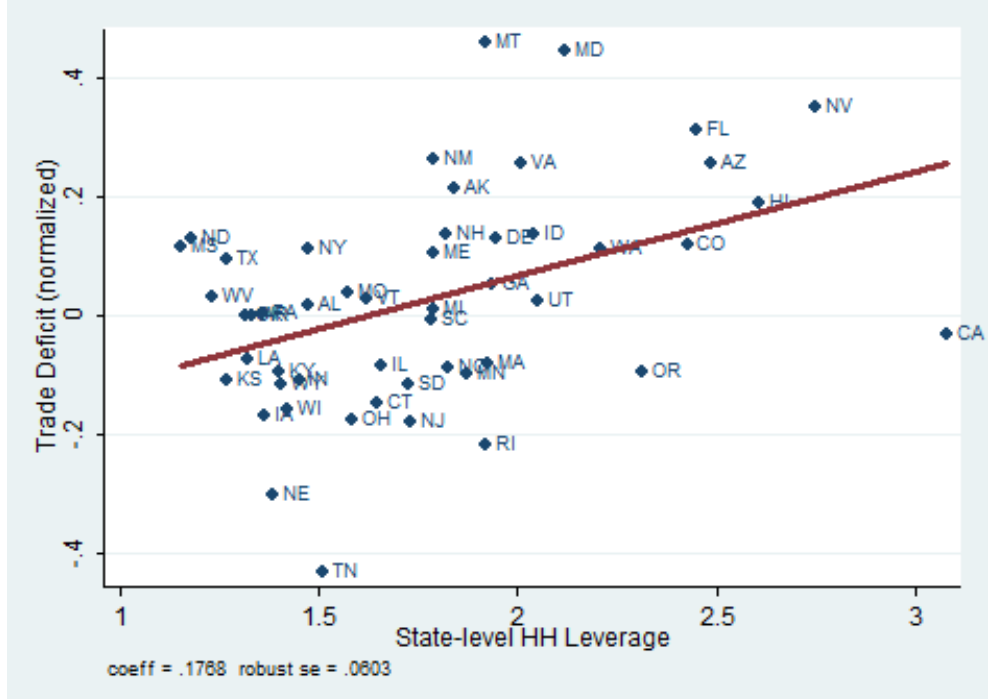

Notes: This figure shows the relationship between the state -level (normalized) trade deficit, calculated as total expenditure minus total sales, divided by the average of total expenditure and total sales: TradeDeficit $i=\frac{\sum_{n} X_{i n}-\sum_{n} X_{n i}}{0.5 \cdot\left(\sum_{n} X_{i n}+\sum_{n} X_{n i}\right)}$ 
Figure 6: Share of Jobs Lost in Manufacturing vs. HH Leverage

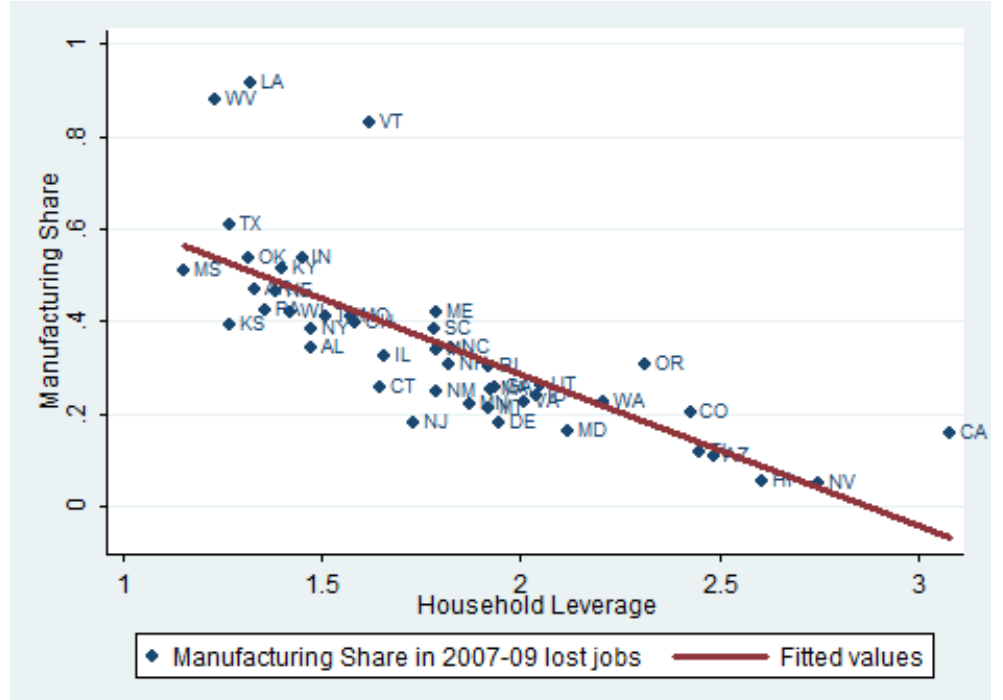

Notes: This figure shows the jobs lost in manufacturing between 2007 and 2009 as a share of the total jobs lost in that state.

Figure 7: The transmission of boom and bust through trade

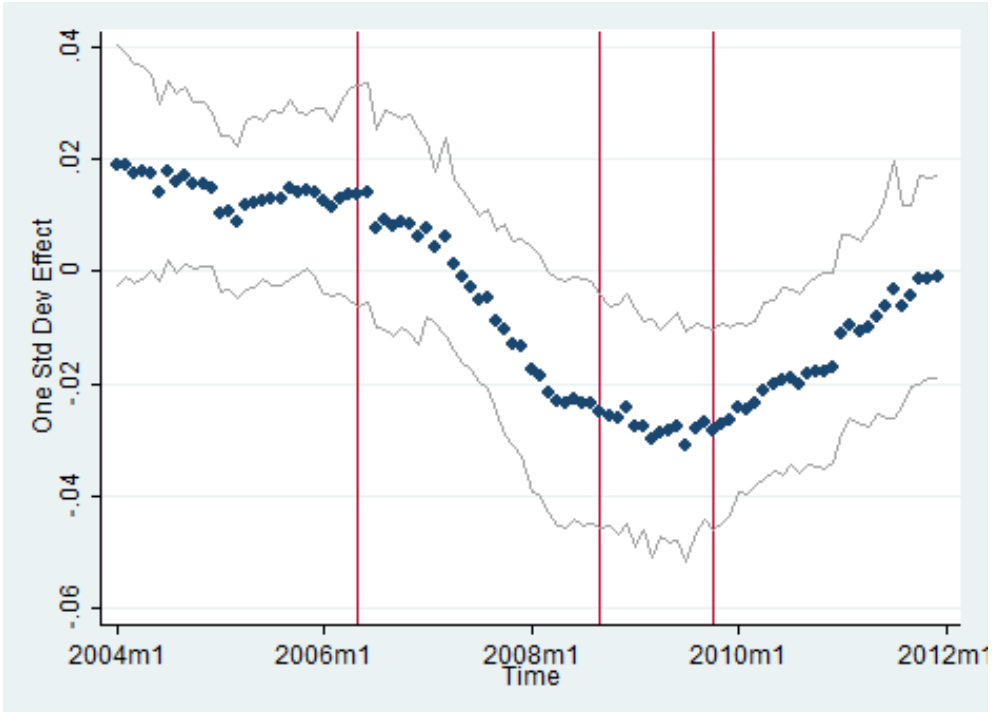

Notes: This graph shows coefficients from WLS regressions of employment growth on the trade demand shock, including state and industry fixed effects. Each regression is estimated for a 2-year interval of employment growth. The light grey lines show the $95 \%$ confidence intervals for twoway-clustered standard errors. The red lines show important events during the Great Recession: (i) The time at which the Case-Shiller house price index peaks (May 2006), (ii) the fall of Lehman (Sept 2008), and (iii) the month at which the national unemployment rate peaks at $10 \%$ (Oct 2009). 
Figure 8: Distance Effect on Trade vs. Value-to-Weight Ratio

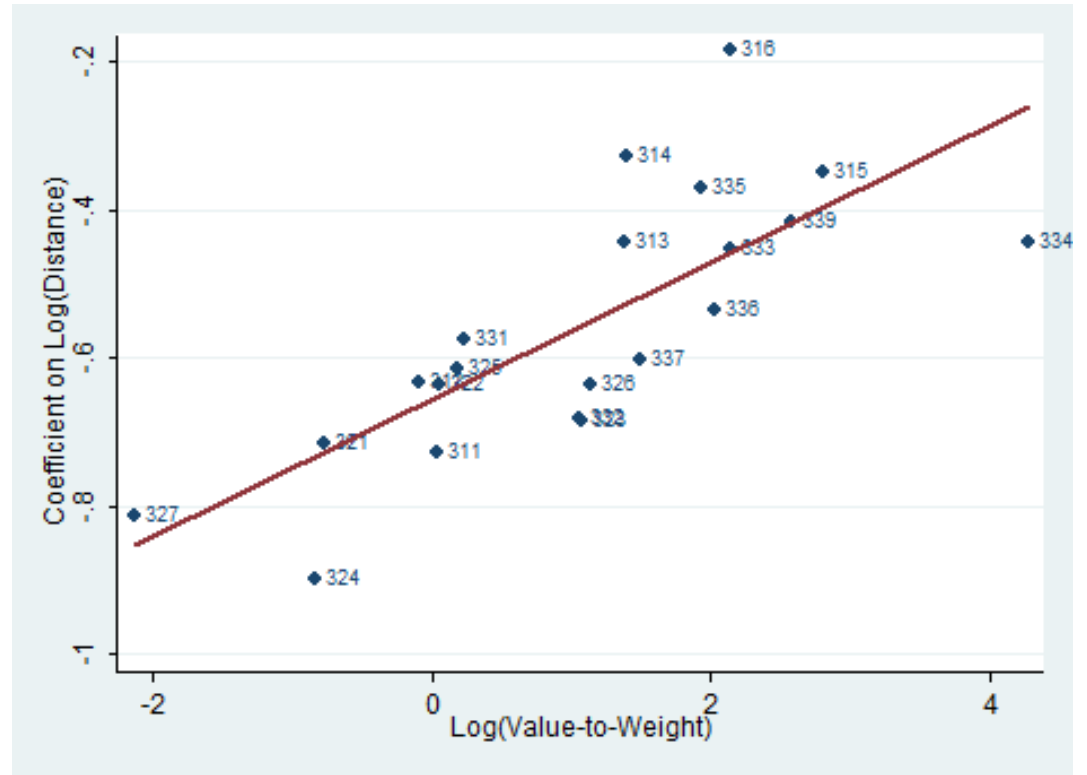

Notes: This figure plots the distance effect on trade flows against the industry-level value-to-weight ratio.

Figure 9: Export Dependence, Employment Growth and HH Leverage

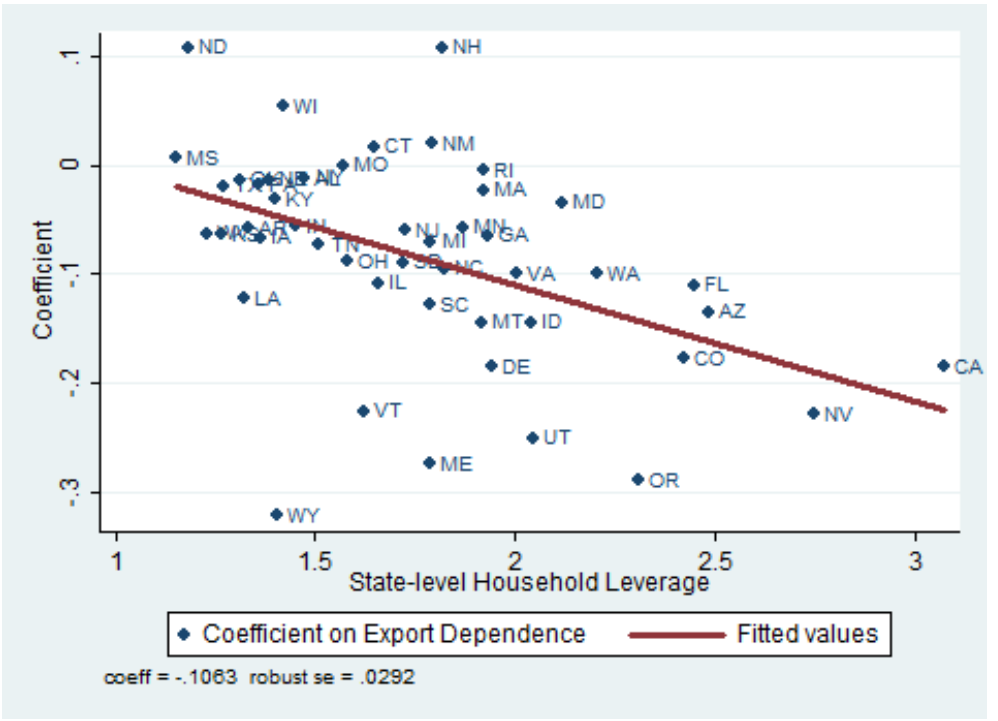

Notes: The graphs shows the coefficients on export dependence from the estimation of equation 3, plotted against state-level leverage. 
Figure 10: County Loan growth, within State

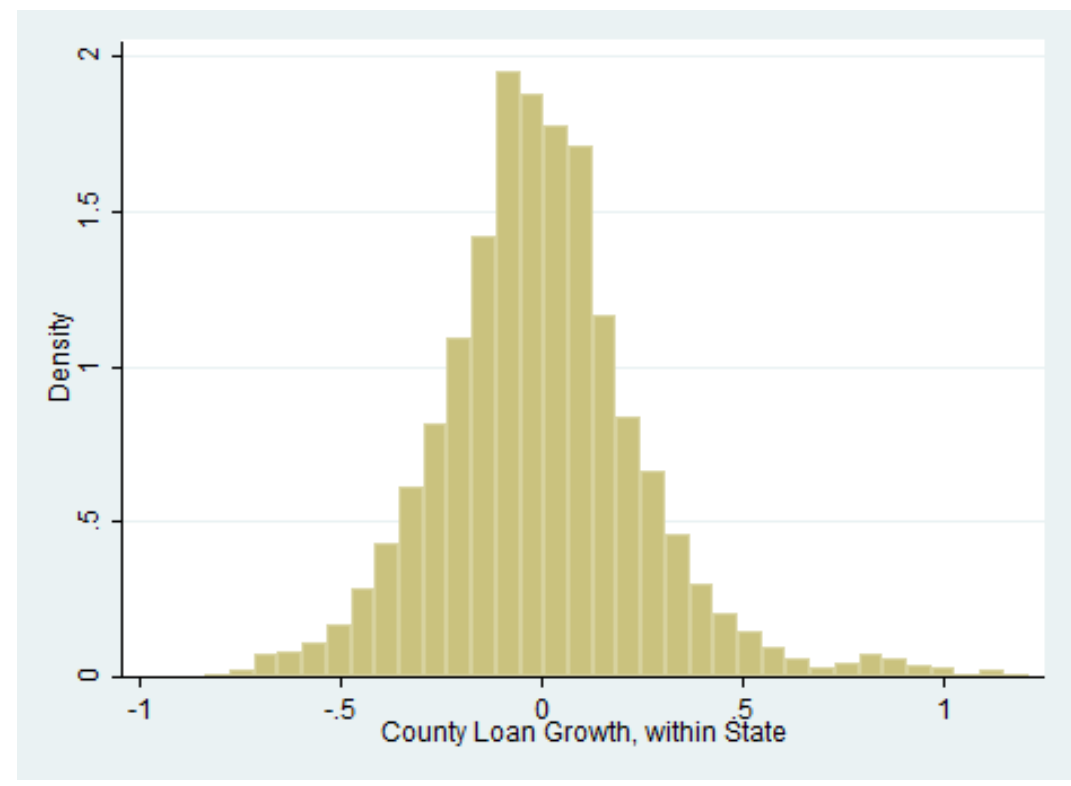

Notes: This figure shows a histogram of loan growth at the county level, demeaned at the state-level.

Figure 11: Employment Response in Trade Model, Autarky Model, and Data

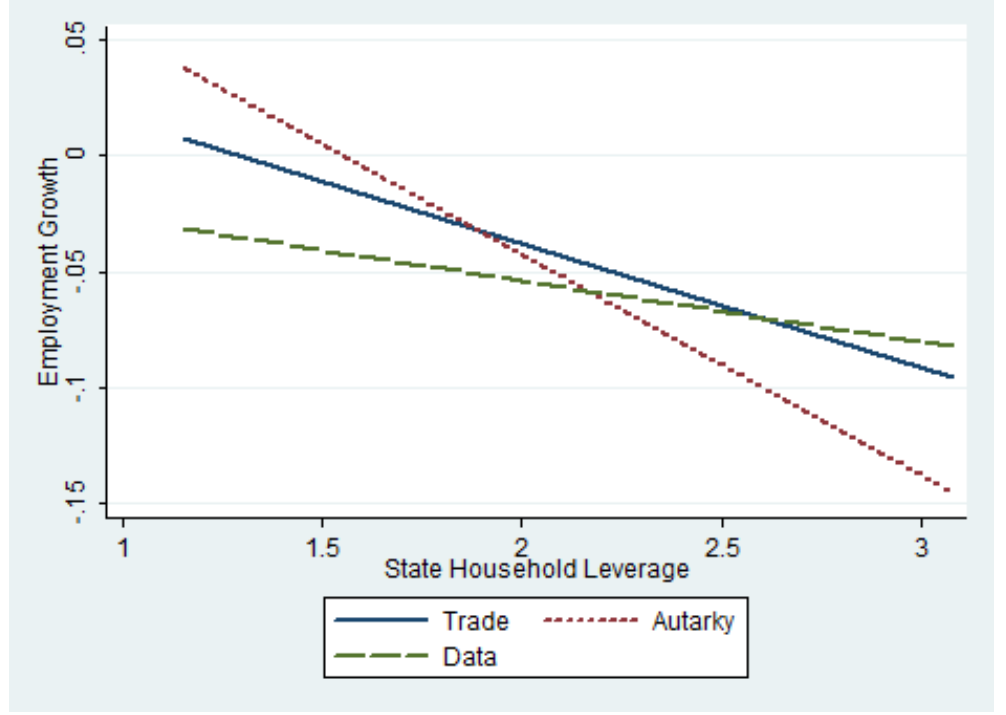

Notes: This graph shows fitted regression lines estimating the relationship between state-level household leverage and employment growth. The dashed, solid, and dotted line use employment growth in the data, trade model, and closed economy model, respectively. 
Table 1: Summary statistics of growth rates and TDS

\begin{tabular}{lccccc}
\hline \hline & Mean & Median & StdDev & 10th & 90th \\
\hline Employment Growth 2007-09 & -.08 & -.08 & .16 & -.26 & .11 \\
Earnings Growth 2007-09 & -.06 & -.08 & .2 & -.28 & .17 \\
Av. Wage Growth 2007-09 & .02 & .01 & .1 & -.08 & .12 \\
TDS & 1.82 & 1.75 & .35 & 1.44 & 2.34 \\
\hline \hline
\end{tabular}

Notes: This table shows summary statistics for variables at the state-industry level: Employment growth, growth of the total wage bill, growth of average wages, and the trade demand shock (as defined in the text).

Table 2: Summary statistics of employment and wages in 2007

\begin{tabular}{lccccc}
\hline \hline & Mean & Median & StdDev & 10th & 90 th \\
\hline Employment 2007 & 12005 & 5445 & 18305 & 1039 & 29745 \\
Earnings 2007 (Mil.) & 594 & 246 & 1057 & 45 & 1437 \\
Av. Wage 2007 & 47220 & 45044 & 13371 & 32910 & 64152 \\
\hline \hline
\end{tabular}

Notes: This table shows summary statistics for variables at the state-industry level: Employment, total wage bill, and the average wage.

Table 3: The Effect of the Trade Demand Shock on Industry Growth

\begin{tabular}{lcccccc}
\hline \hline & $(1)$ & $(2)$ & $(3)$ & $(4)$ & $(5)$ & $(6)$ \\
& Employment 2007-09 & Earnings & 2007-09 & Av. Wage 2007-09 \\
\hline TDS & $-0.090^{* * *}$ & $-0.095^{* * *}$ & $-0.115^{* * *}$ & $-0.135^{* * *}$ & -0.025 & $-0.040^{* * *}$ \\
& $(0.027)$ & $(0.017)$ & $(0.032)$ & $(0.023)$ & $(0.021)$ & $(0.014)$ \\
& & & & & & \\
Observations & 1,519 & 1,519 & 1,519 & 1,519 & 1,519 & 1,519 \\
R-squared & 0.402 & 0.568 & 0.428 & 0.548 & 0.232 & 0.280 \\
Industry FE & $\checkmark$ & $\checkmark$ & $\checkmark$ & $\checkmark$ & $\checkmark$ & $\checkmark$ \\
State FE & $\checkmark$ & $\checkmark$ & $\checkmark$ & $\checkmark$ & $\checkmark$ & $\checkmark$ \\
Specification & OLS & WLS & OLS & WLS & OLS & WLS \\
\hline \hline
\end{tabular}

Notes: This table shows results for regressions of industry growth on the trade demand shock. An observation is a state-industry cell. Weighted least squares specifications use 2007 employment levels as weights. Standard errors are clustered at the state and industry level. 
Table 4: The Effect of the Trade Demand Shock on Manufacturing Industries

\begin{tabular}{lcccccc}
\hline \hline & $(1)$ & $(2)$ & $(3)$ & $(4)$ & $(5)$ & $(6)$ \\
& Employment $2007-09$ & Earnings & $2007-09$ & Av. Wage 2007-09 \\
\hline TDS & $-0.089^{* * *}$ & $-0.100^{* * *}$ & $-0.129^{* * *}$ & $-0.134^{* * *}$ & $-0.040^{* *}$ & -0.033 \\
& $(0.034)$ & $(0.031)$ & $(0.042)$ & $(0.045)$ & $(0.020)$ & $(0.023)$ \\
& & & & & & \\
Observations & 793 & 793 & 793 & 793 & 793 & 793 \\
R-squared & 0.383 & 0.547 & 0.401 & 0.509 & 0.168 & 0.283 \\
Industry FE & $\checkmark$ & $\checkmark$ & $\checkmark$ & $\checkmark$ & $\checkmark$ & $\checkmark$ \\
State FE & $\checkmark$ & $\checkmark$ & $\checkmark$ & $\checkmark$ & $\checkmark$ & $\checkmark$ \\
Specification & OLS & WLS & OLS & WLS & OLS & WLS \\
\hline \hline
\end{tabular}

Notes: This table shows results for regressions of industry growth on the trade demand shock, restricting attention to manufacturing industries. An observation is a state-industry cell. Weighted least squares specifications use 2007 employment levels as weights. Standard errors are clustered at the state and industry level.

Table 5: Effect of transport costs on trade flows in gravity model

\begin{tabular}{lc}
\hline \hline & $(1)$ \\
& $\log ($ Trade Flow $)$ \\
\hline $\log ($ Distance $)$ & $-0.667^{* * *}$ \\
& $(0.00748)$ \\
$\log ($ Distance $) \cdot \log ($ Value-to-Weight) & $0.0803^{* * *}$ \\
& $(0.00438)$ \\
Constant & $5.576^{* * *}$ \\
& $(0.117)$ \\
Observations & \\
R-squared & 18,594 \\
Origin-Industry FE & 0.798 \\
Destination-Industry FE & Yes \\
\hline \hline
\end{tabular}

Notes: This table shows results for a gravity regression of within-U.S. trade flows. 
Table 6: Using Variation in Transport Cost to Identify the Trade Channel

\begin{tabular}{lccc}
\hline \hline & $(1)$ & $(2)$ & $(3)$ \\
& TDS & Employment 2007-09 & Earnings 2007-09 \\
\hline TDS-IV & $0.752^{* * *}$ & & \\
& $(0.112)$ & & \\
TDS & & $-0.105^{* * *}$ & $-0.109^{* *}$ \\
& & $(0.0295)$ & $(0.0484)$ \\
& & \\
Observations & 793 & 793 & 793 \\
R-squared & 0.938 & 0.547 & 0.509 \\
Industry FE & $\checkmark$ & $\checkmark$ & $\checkmark$ \\
State FE & $\checkmark$ & $\checkmark$ & $\checkmark$ \\
Specification & WLS & IV-WLS & IV-WLS \\
\hline \hline
\end{tabular}

Notes: This table shows results for the first and second stage, using the trade demand shock constructed from predicted trade flows as an instrument for the trade demand shock using actual trade flows. The first column shows the first stage relationship, and columns 2 and 3 show second stage relationships, using employment and earnings growth, respectively.

Table 7: The external shock

\begin{tabular}{lccc}
\hline \hline & $(1)$ & $(2)$ & $(3)$ \\
Dependent Variable & Employment 2007-09 & Earnings 2007-09 & Av. Wage 2007-09 \\
\hline & & & \\
External TDS & $-0.070^{* * *}$ & $-0.113^{* * *}$ & $-0.043^{* *}$ \\
& $(0.023)$ & $(0.035)$ & $(0.019)$ \\
& & & \\
Observations & 1,455 & 1,455 & 1,455 \\
R-squared & 0.566 & 0.548 & 0.286 \\
Industry FE & $\checkmark$ & $\checkmark$ & $\checkmark$ \\
State FE & $\checkmark$ & $\checkmark$ & $\checkmark$ \\
Specification & WLS & WLS & WLS \\
\hline \hline
\end{tabular}

Notes: This table shows results for regressions of growth of employment growth and earnings growth at the state-industry level on the external trade demand shock. The external trade demand shock is defined as External $\operatorname{TDS}_{i}^{k}=\sum_{n \neq i} \frac{X_{n i}^{k}}{\sum_{n \neq i} X_{n i}^{k}} L_{e v}$. Standard errors are clustered at the state and industry level. 
Table 8: Placebo Trade Demand Shock Through Reverse Trade Flows

\begin{tabular}{lccc}
\hline \hline & $(1)$ & $(2)$ & $(3)$ \\
& Employment 2007-09 & Earnings 2007-09 & Av. Wage 2007-09 \\
\hline \multirow{2}{*}{ TDS } & $-0.0871^{* * *}$ & $-0.134^{* * *}$ & $-0.0471^{* *}$ \\
& $(0.0228)$ & $(0.0325)$ & $(0.0233)$ \\
Reverse TDS & -0.0135 & -0.00134 & 0.0122 \\
& $(0.0292)$ & $(0.0415)$ & $(0.0286)$ \\
Observations & 1,518 & & \\
R-squared & 0.568 & 1,518 & 1,518 \\
Industry FE & $\checkmark$ & 0.548 & 0.281 \\
State FE & $\checkmark$ & $\checkmark$ & $\checkmark$ \\
\hline \hline
\end{tabular}

Notes: The variable Reverse-TDS conducts a placebo test. It is calculated just like the trade demand shock variable at the state-industry level, but using import flows instead of export flows. That is, ReverseTD $S_{i}^{k}=\sum_{n} \frac{X_{i n}^{k}}{\sum_{n} X_{i n}^{k}} L e v 06_{n}$, whereas $T D S_{i}^{k}=\sum_{n} \frac{X_{n i}^{k}}{\sum_{n} X_{n i}^{k}} L e v 06_{n}$. All estimations are carried out weighting with 2007 employment. Standard errors are twoway-clustered at the state and industry level.

Table 9: Robustness: Internal Shipments Share

\begin{tabular}{lcc}
\hline \hline & $(1)$ & $(2)$ \\
Dependent Variable & Employment 2007-09 & Earnings 2007-09 \\
\hline TDS & $-0.089^{* *}$ & $-0.144^{* *}$ \\
& $(0.042)$ & $(0.061)$ \\
Observations & & \\
R-squared & 1,527 & 1,536 \\
Industry FE & 0.580 & 0.556 \\
State FE & Yes & Yes \\
State FE $\times$ Internal Trade Share & Yes & Yes \\
Specification & Yes & Yes \\
\hline \hline
\end{tabular}

Notes: This table shows results for regressions of growth of employment growth and labor income growth at the state-industry level on the trade demand shock. The estimations control for the share of output shipped internally, interacted with a full set of state fixed effects. Standard errors are clustered at the state and industry level. 
Table 10: Robustness: Industry-specific Demand Shocks

\begin{tabular}{lcccc}
\hline \hline & $(1)$ & $(2)$ & $(3)$ & $(4)$ \\
Dependent Variable & Employment $2007-09$ & Earnings & $2007-09$ \\
\hline & & & & \\
TDSI & $-0.101^{* * *}$ & $-0.111^{* * *}$ & $-0.110^{* * *}$ & $-0.143^{* * *}$ \\
& $(0.024)$ & $(0.015)$ & $(0.030)$ & $(0.022)$ \\
& & & & \\
Observations & 1,526 & 1,526 & 1,526 & 1,526 \\
R-squared & 0.394 & 0.571 & 0.417 & 0.548 \\
Industry FE & $\checkmark$ & $\checkmark$ & $\checkmark$ & $\checkmark$ \\
State FE & $\checkmark$ & $\checkmark$ & $\checkmark$ & $\checkmark$ \\
Specification & OLS & WLS & OLS & WLS \\
\hline \hline
\end{tabular}

Notes: This table shows results for regressions of growth of employment growth and labor income growth at the state-industry level on the trade demand shock with industry-specific shocks. It is defined as $T D S I_{i}^{k}=\sum_{n} \frac{X_{n i}^{k}}{Y_{i}^{k}} \frac{L e v_{n}}{\mu^{k}}=\frac{T D S_{i}^{k}}{\mu^{k}}$, where $\mu^{k}$ is the relative growth of labor payments of industry $k$ in all of the U.S.. Standard errors are clustered at the state and industry level.

Table 11: Differential Effects: Industries producing differentiated vs. homogeneous products

\begin{tabular}{|c|c|c|c|c|}
\hline \multirow[b]{2}{*}{ Dependent Variable } & (1) & $(2)$ & $(3)$ & $(4)$ \\
\hline & \multicolumn{2}{|c|}{ Employment 2007-09 } & \multicolumn{2}{|c|}{ Earnings 2007-09 } \\
\hline \multirow[t]{2}{*}{ TDS } & -0.001 & $-0.060 * *$ & -0.032 & $-0.086^{* *}$ \\
\hline & $(0.048)$ & $(0.025)$ & $(0.068)$ & $(0.037)$ \\
\hline \multirow[t]{2}{*}{ TDS $\cdot$ Diff } & $-0.133^{* * *}$ & $-0.069^{* * *}$ & $-0.147^{* *}$ & $-0.082^{* *}$ \\
\hline & $(0.048)$ & $(0.021)$ & $(0.069)$ & $(0.032)$ \\
\hline Observations & 796 & 796 & 800 & 798 \\
\hline R-squared & 0.367 & 0.546 & 0.385 & 0.508 \\
\hline Industry FE & Yes & Yes & Yes & Yes \\
\hline State FE & Yes & Yes & Yes & Yes \\
\hline Specification & OLS & WLS & OLS & WLS \\
\hline
\end{tabular}

Notes: This table shows results for regressions of growth of employment and earnings at the state-industry level on the trade demand shock and the interaction of the trade demand shock and the index of product differentiation. The first two columns give results for a employment growth, columns 3-4 give results for labor income growth. Standard errors are clustered at the state and industry level. 
Table 12: County-Level Employment Growth in Tradable Industries

\begin{tabular}{lcc}
\hline \hline & $(1)$ & $(2)$ \\
Dependent Variable & Tradable & Employment 2007-09 \\
\hline \multirow{2}{*}{ TDS-County } & $-0.236^{* *}$ & $-0.241^{* * *}$ \\
& $(0.104)$ & $(0.067)$ \\
HH Leverage & -0.013 & 0.000 \\
& $(0.009)$ & $(0.009)$ \\
& & \\
Observations & 2,193 & 2,193 \\
R-squared & 0.093 & 0.182 \\
State FE & $\checkmark$ & $\checkmark$ \\
Specification & OLS & WLS \\
\hline \hline
\end{tabular}

Notes: This table shows results for regressions of tradable employment growth at the county-level on the trade demand shock. Tradable industries are defined as industries producing or shipping tradable goods, i.e. manufacturing and wholesale trade. Standard errors are clustered at the state level.

Table 13: County-Level Employment Growth in Nontradable Industries

\begin{tabular}{lcc}
\hline \hline & $(1)$ & $(2)$ \\
Dependent Variable & Nontradable Employment 2007-09 \\
\hline \multirow{2}{*}{ TDS-County } & -0.020 & 0.002 \\
& $(0.025)$ & $(0.034)$ \\
HH Leverage & $-0.015^{* * *}$ & $-0.021^{* * *}$ \\
& $(0.005)$ & $(0.005)$ \\
& & \\
Observations & 2,189 & 2,189 \\
R-squared & 0.149 & 0.390 \\
State FE & $\checkmark$ & $\checkmark$ \\
Specification & OLS & WLS \\
\hline \hline
\end{tabular}

Notes: This table shows results for regressions of tradable employment growth at the county-level on the trade demand shock. Nontradable industries are defined as all industries except manufacturing and wholesale trade. Standard errors are clustered at the state level. 
Table 14: Least Squares Results

\begin{tabular}{lcccc}
\hline \hline & $(1)$ & $(2)$ & $(3)$ & $(4)$ \\
& Employment Tradables 2007-09 & Employment Nontradables 2007-09 \\
\hline \multirow{2}{*}{ TDS-County } & $-0.241^{* * *}$ & $-0.241^{* * *}$ & 0.003 & 0.003 \\
& $(0.065)$ & $(0.066)$ & $(0.033)$ & $(0.034)$ \\
HH Leverage & -0.000 & -0.001 & $-0.021^{* * *}$ & $-0.021^{* * *}$ \\
& $(0.009)$ & $(0.009)$ & $(0.005)$ & $(0.005)$ \\
Loan Growth & 0.008 & & -0.001 & \\
Loan + OLC Growth & $(0.016)$ & & $(0.005)$ & \\
& & -0.008 & & 0.005 \\
& & $(0.010)$ & & \\
Observations & & & & \\
R-squared & 2,138 & 2,138 & 2,134 & $0.007)$ \\
State FE & 0.184 & 0.185 & 0.394 & Yes \\
Specification & Yes & Yes & Yes & WLS \\
\hline \hline
\end{tabular}

Notes: The table shows regression results from OLS regressions of county employment growth in tradables and nontradables. Loan Growth measures loan growth in a county using the outstanding stock of loans of banks that have branches in that county. Loan + OLC Growth measures the growth of outstanding loans plus open lines of credit. Standard errors are clustered at the state level. 
Table 15: Least Squares Results: Counties Dominated by Large Banks

\begin{tabular}{lcccc}
\hline \hline & $(1)$ & $(2)$ & $(3)$ & $(4)$ \\
& Employment Tradables 2007-09 & Employment Nontradables 2007-09 \\
\hline \multirow{2}{*}{ TDS-County } & & & & \\
& $-0.225^{* * *}$ & $-0.225^{* * *}$ & 0.008 & 0.008 \\
HH Leverage & $(0.079)$ & $(0.079)$ & $(0.039)$ & $(0.040)$ \\
& -0.009 & -0.009 & $-0.024^{* * *}$ & $-0.024^{* * *}$ \\
Loan Growth & $(0.011)$ & $(0.011)$ & $(0.006)$ & $(0.007)$ \\
& 0.010 & & 0.002 & \\
Loan + OLC Growth & $(0.023)$ & & $(0.007)$ & 0.010 \\
& & -0.001 & & $(0.010)$ \\
Observations & & $(0.014)$ & & 1,174 \\
R-squared & 1,175 & 1,175 & 1,174 & 0.460 \\
State FE & 0.239 & 0.238 & 0.457 & Yes \\
Specification & Yes & Yes & Yes & WLS \\
\hline
\end{tabular}

Notes: The table shows regression results from OLS regressions of county employment growth in tradables and nontradables, restricting attention to counties in which large banks account for more than half of the market. Loan Growth measures loan growth in a county using the outstanding stock of loans of banks that have branches in that county. Loan + OLC Growth measures the growth of outstanding loans plus open lines of credit. Standard errors are clustered at the state level.

Table 16: Instrument Correlations

\begin{tabular}{ccccc}
\hline \hline Instrument & Construction-Share & Leverage & TDS-County & Deposits-to-Emp \\
NCF-Share & $-0.048^{* * *}$ & 0.278 & 0.048 & 33.259 \\
& $(0.014)$ & $(0.316)$ & $(0.029)$ & $(34.300)$ \\
NP-Loans & $-0.557^{* *}$ & 1.281 & 0.378 & 712.238 \\
& $(0.220)$ & $(3.518)$ & $(0.399)$ & $(618.233)$ \\
Illiq-Assets & $0.055^{*}$ & 0.300 & -0.002 & -70.078 \\
& $(0.032)$ & $(0.420)$ & $(0.042)$ & $(43.014)$ \\
\hline \hline
\end{tabular}

Notes: The table shows regression coefficients from regressions of the column variables on the row variables (i.e. the instruments) and a set of state fixed effects. Each cell corresponds to a coefficient from a separate regression. All regressions are at the county-level, weighted by total county employment. Standard errors are clustered at the state level. 
Table 17: IV Results for Credit Channel

\begin{tabular}{lcc}
\hline \hline & $(1)$ & $(2)$ \\
VARIABLES & Employment Tradables 2007-09 & Employment \\
\hline & & \\
TDS-County & $-0.245^{* * *}$ & 0.009 \\
& $(0.063)$ & $(0.036)$ \\
HH Leverage & -0.006 & $-0.012^{* *}$ \\
& $(0.010)$ & $(0.006)$ \\
Loan Growth & -0.030 & 0.063 \\
& $(0.054)$ & $(0.039)$ \\
Construction Share & 0.158 & $-0.230^{* * *}$ \\
& $(0.193)$ & $(0.074)$ \\
& & \\
Observations & 2,138 & 2,134 \\
R-squared & 0.182 & 0.350 \\
State FE & Yes & Yes \\
Specification & IV-WLS & IV-WLS \\
\hline \hline
\end{tabular}

Notes: This table shows results for regressions of tradable and nontradable employment growth at the county-level. Tradable industries are defined as industries producing or shipping tradable goods, i.e. manufacturing and wholesale trade. Standard errors are clustered at the state level.

Table 18: State-Industry-Level Employment Growth

\begin{tabular}{lcc}
\hline \hline & $(1)$ & $(2)$ \\
VARIABLES & Emp Growth & Emp Growth \\
\hline & & \\
Loan growth $\cdot$ EFD (IV) & 0.032 & -0.117 \\
& $(0.186)$ & $(0.125)$ \\
TDS & $-0.088^{* * *}$ & $-0.093^{* * *}$ \\
& $(0.030)$ & $(0.032)$ \\
& & \\
Observations & 796 & 796 \\
R-squared & 0.358 & 0.536 \\
State FE & Yes & Yes \\
Industry FE & Yes & Yes \\
Specification & IV-OLS & IV-WLS \\
\hline \hline
\end{tabular}

Notes: This table shows results for regressions of employment growth at the state-industry level. EFD stands for the index of external finance dependence as in Rajan and Zingales (1998). 
Table 19: Regressions on Model-Generated Data

\begin{tabular}{lccc}
\hline \hline & $(1)$ & $(2)$ & $(3)$ \\
VARIABLES & Employment Growth & Earnings Growth & Wage Growth \\
\hline TDS & $-0.074^{* * *}$ & $-0.098^{* * *}$ & $-0.025^{* * *}$ \\
& $(0.008)$ & $(0.010)$ & $(0.003)$ \\
& & & \\
Observations & 788 & 788 & 788 \\
R-squared & 0.904 & 0.934 & 0.988 \\
Industry FE & $\checkmark$ & $\checkmark$ & $\checkmark$ \\
State FE & $\checkmark$ & $\checkmark$ & $\checkmark$ \\
Specification & WLS & WLS & WLS \\
\hline \hline
\end{tabular}

Notes: This table shows results for regressions of model-generated data on employment, earnings and wage growth on the trade demand shock variable. 
Table 20: List of Industries in Sample

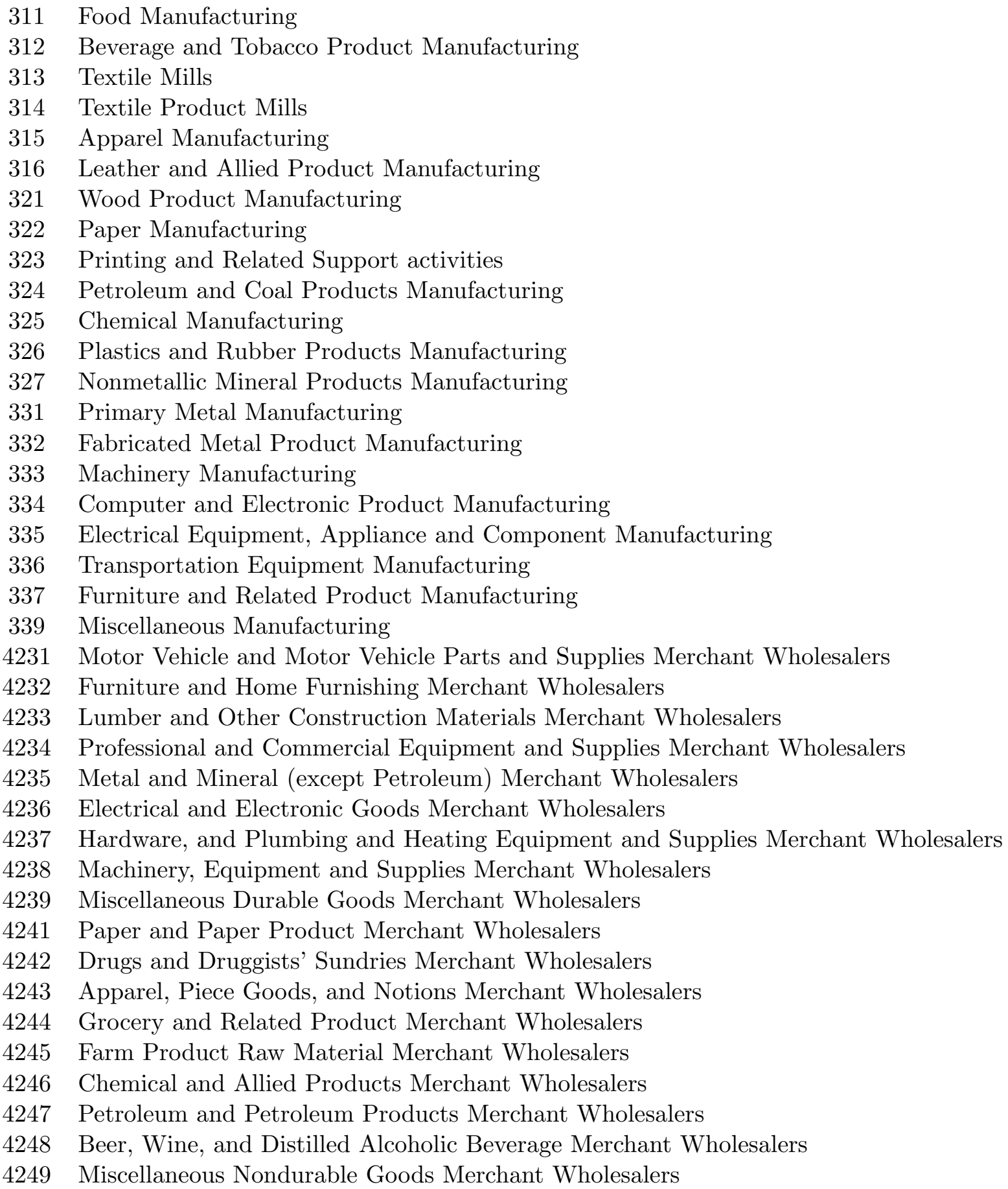

